\title{
Bir Sultan Ailesinin İnşâsı: Padişah II. Abdülhamid'in Kızlarından Nâile Sultan ve Damat Arif Hikmet Paşa'nın İzdivacı
}

\section{Building a Sultan Family: Marriage of Naile Sultan, The Daughter of Padishah Abdulhamid II, and Arif Hikmet Pasha}

\author{
Lale Uçan* (1)
}

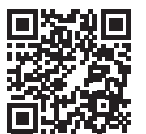

*Dr. Öğr. Üyesi, Fatih Sultan Mehmet Vakıf Üniversitesi, Edebiyat Fakültesi, Tarih Bölümü, İstanbul, Türkiye

\section{ORCID: L.U. 0000-0002-4393-743X}

Sorumlu yazar/Corresponding author: Lale Uçan,

Fatih Sultan Mehmet Vakıf Üniversitesi, Edebiyat Fakültesi, Tarih Bölümü, İstanbul, Türkiye

E-posta/E-mail: lucan@fsm.edu.tr

Başvuru/Submitted: 06.07.202

Revizyon Talebi/Revision Requested:

08.10.2021

Son Revizyon/Last Revision Received:

19.10.2021

Kabul/Accepted: 20.10 .2021

\section{Atıf/Citation:}

Ucan, Lale. "Bir Sultan Ailesinin Inşâsı: Padişah II. Abdülhamid'in Kızlarından Nâile Sultan ve Damat Arif Hikmet Paşa'nın Izdivacı." Tarih Dergisi - Turkish Journal of History, 75 (2021): 191-221. https://doi.org/10.26650/iutd.963184

\section{ÖZ}

Osmanlı́nın son yüzyılında pek çok alanda değişim ve dönüşüm yaşanırken onun etkileri, toplum yapısından ekonomik siyasal düzenlemelere; devlet teşkilatından hukuk, eğitim ve aile hayatına kendisini göstermiştir. Makalede II. Abdülhamid'in kızlarından Nâile Sultan'ın özelinde padişah kızının aile kurma süreci, bu gelişmeler doğrultusunda anlatılmıştır. Hanedan kızlarının evlendirilmesi İslâmî değerler, geleneksel yaşantı ve dönemin kendine has özellikleri ile şekillenmiştir. Bu evlilikler, hanedanın şan ve şerefi ile birlikte sarayın temsili için bir imkan sağladığı gibi sultanefendinin yeni yaşam alanındaki konumu için de önemli bir adımdır. Nâile Sultan'a eş seçiminin yanı sıra düğün hazırlıkları, nikâhı ve bu sebeple ona tahsis edilen mekân ele alınırken konu saray, gelin ve damat açısından bütünlük içinde değerlendirilmiştir.

Anahtar sözcükler: II. Abdülhamid, Nâile Sultan, Arif Hikmet Paşa, Evlilik, Çeyiz, Sâhilsaray

\section{ABSTRACT}

In the last century, the Ottoman Empire underwent change and transformation in many areas ranging from the social structure and economic and political regulations, through state organization to law, education and family life. This study elucidates the process of establishing a family of a padishah's daughter in line with these developments, taking Nâile Sultan's, marriage, one of Abdulhamid's daughters as an example. The marriage of dynasty girls was shaped by Islamic values, traditional life, and the unique characteristics of the era. These marriages, along with the glory and honor of the dynasty, provided an opportunity to represent the palace, as well as an important step for the sultan's position in his new living space. While discussing the choice of spouse's wedding preparations, marriage, and the venue, the subject has been evaluated in integrity in terms of the palace, the bride and the groom.

Keywords: Abdulhamid II, Naile Sultan, Arif Hikmet Pasha, Marriage, Dowry, Shore Place 


\section{Extended Abstract}

Wedding in the Ottoman palace is a dynastic ceremony in terms of social, cultural, traditional and economic aspects. As much as the conditions of the era shaped this ceremony, the wedding showcaces the power of the palace, and serves as an environment where the state exhibits its power. This study examines, the process of building a dynasty family using the case of Nâile Sultan, one of the daughters of Abdullhamid II (1842-1918), as an example. Her marraige took place during the reign of her father Abdulhamid II. The period, which was an important stage in her life from the choice of a husband and dowry preparations, through her wedding to the shore palace allocated to her has been evaluated. Nâile Sultan was born on January 9 1884. She was only able to see her mother, Dilpesend Kadın, until she was 17. In the summer of 1901, Dilpesend Kadın became sick and died. Nâile Sultan, was a pianist, harpist and violist. She displayed these skills during the visit of the Emperor Wilhem II (1859-1941) and his wife, Empress Augusto Victoria to Istanbul. Upon returning to her country, the Empress relayed that they left Istanbul with good memories and that Nâile Sultan's musical talent was remarkable for her age. She sent her gifts of toys.

The change and transformation that took place in the last century of the Ottoman Empire was experienced in many layers of the social structure. Dynasty weddings and the sultan's family were also affected by these developments. Palace marriages should be looked at holistically, both because they were formed within the framework of ancient tradition, and because of the special aspects they contain. Several parameters guided the issue of choosing a husband for Nâile Sultan. First, the determination of the groom by the woman and the shaping of the marriage with the consent of the bride can be read as a sign of superiority. The negative marriages of Nâile Sultan sisters, Zekiye and Nâime Sultans also directed her marriage. Nureddin and Kemaleddin, sons of Gazi Osman Pasha, were chosen for Zekiye and Nâime Sultans. Abdulhamid II rejected Gazi Osman Pasha's younger son Cemaleddin for his daughter, Nâile Sultan, because Nureddin's and Kemaleddin's attitudes, which were not suited for marriage, and as result, affected the sultan's husband choice for Nâile Sultan. After these two negative marriages, the good qualities and paternal discipline of Abdurrahman Pasha's son Arif Hikmet were valued in the choice of the groom. In this process, the issue of who the groom's father would be was as much a priority as the choice of the groom. The groom's father, Abdurrahman Pasha, was a figure that the sultan found to be successful. Lastly, the happiness and felicity of the bride in the marriage was requested for the daughter of the padishah. Nâile Sultan's wedding took place in Yıldız Palace on, a winter day, on February 27, 1905.

Dowry has a significant place the in Ottoman society. If the bride is a member of a dynasty, its magnificence becomes even more prominent. Sultan Abdulhamid II approached the dowry issue sensitively and covered the dowry expenses of some of his daughters himself. Nâile 
Sultan's veil, gowns, fur, and shoes were embroidered. Embroidery was present in all sultan's clothes. The sultan, whose dress and shoes were prepared as a set, were white, blue, pink and amethyst in color. Nâile Sultan's outfits were completed by a large diamond solitaire gold ring, earrings surrounded by large gold stones, a bracelet surrounded by large-medium gold stones, large-medium gold stones and a crown decorated with small diamonds. Engagement set was prepared for the groom.

As the weddings of the sultans were held together, sometimes the wedding dates were also postponed. One of the most striking points about this wedding is that the economic issues and the conditions of the country were taken into consideration. It was underlined that there was no need for banquets held in sultan's palaces during the period. Although an attitude befitting the sultan's personality was displayed, during the reign of Abdulhamid II, the number of people who were served meals at weddings decreased in comparison with the previous weddings. Nâile Sultan's wedding dinner confirms this information. Meanwhile, upon looking at the wedding expenses of Nâile Sultan, this was determined in the wedding expenses of Nâile Sultan, even though the giving of gifts and presents in some wedding ceremonies was abolished.

After Arif Hikmet became the groom positive developments in his salary and societal status, along with retirements, plans were noticed. He received a sihriyyet salary as a groom. Sihriyyet salary is the salary that the groom receives due to his duty and the money he receives upon the approval of his marriage. This marriage did not only have financial benefits for the groom. The salary of Nâile Sultan was also adjusted. Nâile Sultan's salary was higher than Arif Hikmet Pasha's. Among the factors affecting the increase in the salary of the married sultan, was her father's being alive with whom she has a strong relationship. The shore palace allocated to Nâile Sultan in Kuruçeşme is among the precious districts in Istanbul at the beginning of the 19th century. The shore palace and the mansion behind it, which belonged to the former Naval Minister Hasan Pasha, were given to the sultan for residence. Both structures needed repair. Nâile Sultan and her husband lived in the seaside palace in Kuruçeşme for 19 years between 1905 and 1924. 


\section{Giriş}

Osmanlı sarayında gerek İslâmî kaideler gerekse de gelenek çerçevesinde şekillenen evlilik, hanedan arasında olduğu kadar, topluma yansıyan yönleriyle büyük önem arz eden merasimler arasında yer alır. İlk Osmanlı hükümdarları kızlarını diğer Anadolu hükümdarları, onların oğulları ya da maiyetlerindeki beylerle evlendirmiştir. Bununla birlikte üst düzey devlet adamları, komşu devlet ya da beyliklerin hanedan mensuplarıyla izdivaçlar da söz konusu olmuştur. 18. yüzyıl ve sonrasında Batı'ya yöneliş hız kazanırken; değişimin sosyal, ekonomik ve toplumsal etkileri her alanda olduğu gibi hanedan yaşamını etkilese de sultanefendilere ${ }^{1}$ damat seçimi takip edildiğinde, her dönem sarayın siyasi gücüne fayda sağlayacak kişiler ve oğullarının tercih edildiği görülmektedir².

Bir Sultan Ailesinin İnşâsı: Sultan II. Abdülhamid'in Kızlarından Nâile Sultan ve Damat Arif Hikmet Paşa'nın İzdivacı isimli makalemizde, hanedanın iç halkasında önemli bir yeri olan evlilik konusu Nâile Sultan'ın özelinde değerlendirilecektir. Son dönem sultanefendilerin yaşam şekillerini anlamaya yönelik evlilik mevzusu, damat seçimi, çeyiz-nikâh hazırlıkları, sultanefendiye tahsis edilen mekân bağlamında incelenecektir. Bu yönüyle, Nâile Sultan'ın saray dışındaki yaşama ilk adım atış süreci mercek altına alınacaktır. İktidarların temsil gücünün uzantısı merasimler, gücün teşhir edilmesi için önemli araçlardır³. Sultanefendiler, nikâhları sonrasında kendilerine ihsan edilen yerlerde yaşarlar. Padişah sarayı ve eşlerinin hâneleri yerine bağımsız bir yaşam alanında saray teşkilatı kurmuş olmaları, onlara statü kazanmaları için ortam hazırlamaktadır. Sultanefendiler, padişah sarayını temsilen yeni yaşam alanlarında imparatorluk adâbını ve usûlünü sergilemektedirler ${ }^{4}$. Bu minvâlde, Nâile Sultan'ın izdivacına tüketim kültürü ve yeni yaşamının maddi göstergeleri çerçevesinden de bakılacaktır.

\section{Nâile Sultan’ın Biyografisinden Kısa Bir Kesit}

Osmanlı tahtının 34. Padişahı Sultan II. Abdülhamid'in ${ }^{5}$ dokuz kızı ve sekiz oğlu olmuştur'6 . Nâile Sultan'ın annesi Çerkez asıllı Dilpesend Kadınefendi, Kızılbeg

1 Padişah kızı için kullanılmaktadır.

2 İsmail Hakkı Uzunçarşılı, Osmanlı Devletinin Saray Teşkilatı, Türk Tarih Kurumu, Ankara 1988, s. 157-166; Leslie P. Peirce, Harem-i Hümayun, Osmanlı Imparatorluğu'nda Hükümranlık ve Kadınlar, Tarih Vakfı Yurt Yayınları, İstanbul 1996, s. 87 vd.; A. D. Alderson, Osmanlı Hanedanının Yapısı, yay. haz. Mustafa Armağan, çev. Şerafettin Severcan, İz Yayıncılık, İstanbul 1998, s. 139-149; Çağatay Uluçay, Harem II, Türk Tarih Kurumu, Ankara 1992, s. 89-91.

3 Hakan T. Karateke, Padişahım Çok Yaşa, Kitap Yayınevi, İstanbul 2004, s. 209-210.

4 Tülay Artan, "Boğaziçi’nin Çehresini Değiştiren Soylu Kadınlar ve Sultanefendi Sarayları”, İstanbul, sayı 3, (1992), s. 109-118.

5 Ayşe Osmanoğlu, Babam Sultan Abdülhamid, Timaş, İstanbul 2019, s. 257-274; M. Çağatay Uluçay, Padişahların Kadınları Kızları, Türk Tarih Kurumu, Ankara 1980, s. 244-259.

6 Annesi Nazikeda Kadın olan Ulviye Sultan 1868 yılında dünyaya gelmiştir. 21 Ocak 1872 tarihinde Dolmabahçe Sarayı'nda doğan Zekiye Sultan'ın annesi Bedrifelek Kadınedefendi idi. II. Abdülhamid'in 1876 senesinde 
Maksud Giray ${ }^{7}$ ve Esma Hanım'ın kızıdır ${ }^{8} .1865$ yılında doğduğu söylenen Dilpesend Kadınefendi'nin ${ }^{9}$, Mest-i Ahû, Pakize ${ }^{10}$ ve Mithat isimlerinde kardeşleri olduğu bilgisine ulaşılmıştır. Sultan II. Abdülhamid'in sevgili haremlerinden olmadiğ söylenen ${ }^{11}$ Dilpesend Kadınefendi, uzun boylu ${ }^{12}$, siyah saçlı ve buğday tenlidir. Güzelliğinden ziyâde boyu ve edasıyla anlatılan Dilpesend Kadınefendi ${ }^{13}$, kendi halinde sessiz ve sakince tek evladı olan Nâile Sultan'la birlikte yaşamıştır ${ }^{14}$. Otuz altı yıl kadar süren kısa bir yaşam sonrasında 1901 senesi yazında hastalanan Dilpesend Kadınefendi, bu dönemi acılar içerisinde geçirmiştir. O kadar ki; derdine çare bulunamayan kadınefendinin ağrılarının morfinle dindirilmesi için sultandan izin istenmiştir. Morfin yapılmasına müsaade edilmesi sonrasında, Dilpesend Kadınefendi hayata gözlerini kapamıştır ${ }^{15}$. Mislimelek Hanım, o tarihlerde genç kız olan Nâile Sultan'ın annesinin ölümü ile üzüntüsünden baygınlık geçirdiğini yazmaktadır ${ }^{16}$. Dilpesend Kadınefendi, Yahya Efendi'de bulunan türbeye defnedilmiştir ${ }^{17}$.

Bîdar Kadın'dan doğan kızı Nâime Sultan'dır. Padişah 31 Ekim 1886 tarihinde Yıldız Sarayı'nda hayata gelen evladına, Ayşe ismini vermiştir. Ayşe Sultan'ın annesi, Müşfika Kadınefendi idi. Ayşe Sultan'ın doğumundan yaklaşık yirmi gün sonra Emsâlinur Kadınefendi, Şadiye Sultan’ı hayata getirmiştir. Refia Sultan, 15 Haziran 1891 tarihinde doğmuştur. Annesi İkbâl Sâzkâr idi. Padişah, Hadice Sultan'ın vefatıyla evlat acısı yaşamıştır. 10 Haziran 1897'de doğan sultan daha bir yaşını doldurmadan sebebi belli olmayan bir rahatsızlık sonrasında hayata veda etmiştir. Babası, Hamidiye Etfal Hastanesi’ni Hatice Sultan’ın ölümü sonrasında yaptırmıştır. Sâmiye Sultan'ın annesi İkbâl Saliha Naciye idi. Yaklaşık iki sene kadar hayata tutunan küçük sultan, 24 Ocak 1909 tarihinde hayata gözlerini yummuştur. Şehzâde Mehmed Selim Efendi padişahın ikinci evladı diğer taraftan hayata gelen ilk oğlu idi. Annesi Bedrifelek Kadınefendi, 10 Mart 1872'de Dolmabahçe Sarayı'nda doğumu gerçekleştirmiştir. Bidar Kadınefendi, Nâime Sultan'dan sonra 16 Ocak 1878 tarihinde Abdülkadir Efendi'yi hayata getirmiştir. 11 Şubat 1878'de doğan Ahmed Efendi'nin annesi Bedrifelek Kadınefendi idi. Mezide Kadınefendi, Mehmed Burhaneddin'in annesi idi. Doğum, 18 Aralık 1885 tarihinde gerçekleşmiştir. Sultanın on ikinci çocuğu Abdurrahim Hayri Efendi’nin annesi İkbâl Peyveste idi. 14 Ağustos 1894 tarihinde dünyaya gelmiştir. İkbâl Behice Maan Hanım, 22 Haziran 1901 tarihinde dünyaya gelen ikiz çocukların Mehmed Bedreddin ve Ahmed Nureddin Efendilerin annesi idi. İkiz şehzâdelerin doğumu, Yıldız Sarayı'nda gerçekleşmiştir. İkbâl Naciye Hanım'dan, sultanın son erkek evladı Mehmed Abid Efendi’nin annesi idi. Şehzâde 17 Eylül 1905 tarihinde, Yıldız Sarayı'nda gözlerini dünyaya açmıştır. Ayşe Osmanoğlu, a.g.e., s. 257-274; Çağatay Uluçay, Padişahların Kadınları Kızları, s. 171-183; Alderson, a.g.e., s.297-299.

7 Leyla Açba, Bir Çerkes Prensesinin Harem Hatıraları, yay. haz. Edadil Açba, Timaş Yayınları, İstanbul 2010, s. 66-67.

8 Haremden Sürgüne Bir Osmanlı Prensesi II. Abdülhamid'in Gelini Mislimelek Hanım, İstibdat Döneminin Bilinmeyenlerini Anlatıyor, haz. Nemika Deryal Marşanlığlu, İnkılap, İstanbul 2011, s. 119-120.

9 Alderson, a.g.e., s. 297; Uluçay, Padişahların Kadınları ve Kızları, s. 174.

10 BOA, İ.ML, 80/16, lef 1, 25 III 1314 (6 Haziran 1898).

11 Haremden Sürgüne, s. 119-120.

12 Ömer Faruk Y1lmaz, Sultan II. Abdülhamid Han'in Hayatı, Çamlıca, İstanbul 2013, s. 113.

13 Nahid Sırrı Örik, Bilinmeyen Yaşamlarıyla Saraylılar, yay. haz. Alpay Kabacalı, Türkiye İş Bankası Yayınları, İstanbul 2002, s. 128.

14 Uluçay, Padişahların Kadınları ve Kızları, s. 180; Nahid Sırrı Örik, Abdülhamid'in Haremi, Arba Yayınları, İstanbul 1989, s. 23.

15 Kadınefendinin kanser hastası olduğu bilgisine de ulaşılmıştır. Haremden Sürgüne, s. 119-120; Nahid Sırrı Örik, Nâile Sultan'ın şiddetli bir kum sancısı çektiğini bu sebepten vefat ettiğini yazar. Örik, Bilinmeyen Yaşamlarıla Saraylılar, s. 128.

16 Haremden Sürgüne, s. 119-120.

17 Uluçay, Padişahların Kadınları ve Kızlarl, s. 174; Haremden Sürgüne, s. 120. Yapmış olduğumuz ziyarette Dilpesend Kadınefendi’nin Yahya Efendi Türbesi Mezarlığg'nda defnedildiğini gördük. 
Annesi Dilpesend Kadınefendi'yi ${ }^{18}$ on yedi yaşına kadar görebilen Nâile Sultan'ın ad ${ }^{19}$ Hânedan Defteri'ne Abdülhamid-i sâninin 9 Ocak 1884 tarihinde doğmuş kızı olarak kayıtlıdır ${ }^{20}$. Sultan II. Abdülhamid'in tahta çıktıktan sonra yaklaşık yedi ay kadar Dolmabahçe Sarayı'nda ikamet ettiği düşünüldüğünde, Nâile Sultan'ın Yıldız Sarayı'nda doğduğunu söyleyebiliriz. Pek güzel olduğundan bahsedilen Nâile Sultan ${ }^{21}$ padişahın çocukları arasında yedinci, kıları içerisinde dördüncü sıradadır ${ }^{22}$. Sultan dünyaya geldiğinde ona, istediği şeye muvaffak olan, muzaffer ${ }^{23}$ anlamlarına gelen, Nâile ismi verilmiştir. Yeni doğan sultanefendiye, Padişah Abdülmecid'in kızlarından olup genç yaşta vefat eden halasının ismi uygun görülmüştür. Abdülhamid'in kızı Nâile Sultan’a düşkün olduğu bilgisine dönem hatıratından ulaşılmaktadır ${ }^{24}$. Nâile Sultan'ın piyanist, arpist ve viyolensalist olduğu söylenirken, mûsikî hocasının Lombardi Bey olduğu paylaşılmaktadır ${ }^{25}$. Şâdiye Sultan, kardeşi Nâile Sultan'la birlikte tiyatro temsillerini izlediklerini anlatmaktadır. Sultan II. Abdülhamid'in kendi locasında takip ettiği programlarda, kızları Nâile ve Şâdiye Sultanlar hemen yanındaki locadan etkinliklere iştirak etmişlerdir ${ }^{26}$.

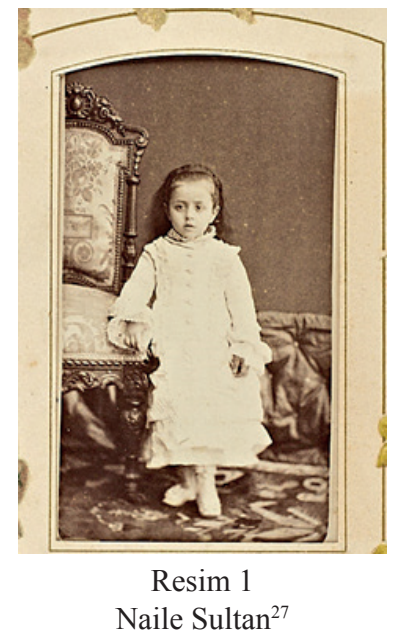

18 Mislimelek Hanım hatıralarında, Dilpesend Kadın’ın Seniha isimli kızının dünyaya geldiğini ancak beş ay kadar yaşayabildiğini aktarmıştır. Haremden Sürgüne, s. 111.

19 Kız kardeşleri Ulviye, Zekiye, Ayşe, Şadiye, Refia, Hatice, Samiye sultanlar; erkek kardeşleri Mehmed Selim, Mehmed Abdülkadir, Ahmed Nuri, Mehmed Burhaneddin, Abdurrahim, Mehmed Bedreddin, Ahmed Nureddin, Mehmed Abid Efendilerdir. A. Osmanoğlu, a.g.e., s. 258-259.

20 BOA, A.DVNSHND, nr. 1, s. 15; Yahya Efendi Türbesi'ne yapmış olduğumuz ziyarette, Naile Sultan'ın mezarının da annesi Dilpesend Kadınefendi ile aynı türbede olduğunu gördük.

21 Haremden Sürgüne, s. 61.

22 Uluçay, Padişahların Kadınları ve Kızları, s. 171-183; Alderson, a.g.e., s. 297-299.

23 Şemseddin Sâmi, "Nâil”, Kâmûs-ı Türkî, Enderun Kitapevi, İstanbul 1989, s. 1453.

24 Şadiye Osmanoğlu, Babam Abdülhamid Saray ve Sürgün Yılları, Timaș Yay., İstanbul 2009, s. 24.

25 Yılmaz Öztuna, II. Abdülhamid: Zamanı ve Şahsiyeti, Kubbealt1, İstanbul 2008, s. 224. Sarayın müzisyenlerinden François Lombardi (1865-1904) olduğunu düşünmekteyiz. François Lombardi, Augusto Lombardi'nin oğludur. Lombardi sarayda Ayşe Sultan'a piyano dersleri vermiş bir isimdir. 1904 yılında ölene kadar da sarayda hizmet etmiştir. Artemur Orkun Gündoğdu, Osmanlı/Türk Müzik Kültüründe Avrupa Müziğinin Yaygınlaşması Süreci ve Levanten Müzikçiler, Başkent Üniversitesi Sosyal Bilimler Enstitüsü, Yüksek Lisans Tezi, Ankara 2016, s. 83.

26 Haremden Sürgüne, s. 107-108, 120.

27 İ.Ü. Nadir Eserler Kütüphanesi, II. Abdülhamid Han Fotoğraf Albümleri, nr. 90904-0007. 
Alman İmparatoru II. Wilhelm (1859-1941) Osmanlı topraklarına ilk ziyaretini 1889 tarihinde gerçekleştirmiştir. Bu gezi sırasında imparatorun eşi Augusto Victoria, haremi ve saray hanımlarını görmek istemiştir. Harem teşkilatı, kuralları ve hiyerarşisinin dış dünyaya kapalı bir ortam olması bir gizem uyandırmıştır. İmparatoriçenin harem ziyaretindeki karşılama töreninde ise bu yıllarda beş yaşlarında olan Nâile Sultan, imparatoriçeye buket takdim etmiştir. İmparatoriçenin protokol kurallarının dışına çıkarak, Nâile Sultan'ın yanaklarından öptüğü anlatılmaktadır. Nâile Sultan da harem çıkışında imparatoriçeye kaldıkları köşke kadar refakat etmiştir ${ }^{28}$. Alman imparatoru ve imparatoriçesi ülkelerine döndüklerinde, İstanbul'dan güzel anılarla ayrıldıklarını paylaşmışlardır. Nâile Sultan'ın mûsikîde yaşına göre dikkate değer kabiliyetini şayân-ı taaccübe varacak seviyede hayretle karşılamışlardır. Bu sebeple, Nâile Sultan'a hediye olarak oyuncak gönderilmiştir ${ }^{29}$. Sonrasında ise, Nâile Sultan'ın kardeşi Şehzâde Burhanedin Efendi ile birlikte Alman imparatoruna ve imparatoriçesine yadigâr olarak gönderdikleri fotoğraftan duyulan memnuniyet bildirilmiştir ${ }^{30}$. Bu tür ziyaretlerin siyasi, ekonomik, kültürel etkilerinin yanı sıra saray çocuklarının nezdindeki yansımaları önemlidir. Saray çocuklarının resmî törenlerde, kendilerine açılan alanda temsil vazifelerini üstlenmelerine şahit olmaktayız. Bu yaklaşım, protokolde kız ve erkek çocuğun birey olarak görülmesi adına ve ona olan saygının ifade şekli olarak kıymetlidir.

Nâile Sultan’ın tespit edebildiğimiz gelirleri arasında Şirket-i Hayriye hisselerini söyleyebiliriz. Şirket-i Hayriye 17 Ocak 1851 tarihinde İstanbul, Adalar ve Boğaziçi arasında düzenli ve güvenli ulaşımı sağlamak amacıyla faaliyete geçen ilk anonim şirkettir. Osmanlı hanedan mensuplarının bu şirket hisselerinde payı olduğu bilinmektedir. Sultan Abdülmecid'in ve Bezmiâlem Valide Sultan'ın ${ }^{31}$ isimleri örnek olarak verebilir. Sultan II. Abdülhamid'in çocuklarının da bu şirket hisselerinde payı vardır. Şirket-i Hayriye hisselerinden beş hisselik pay Şehzâde Burhaneddin Efendi'ye ${ }^{32}$ ayrılmış; Nâime ve Nâile Sultanlara dörderden ${ }^{33}$ sekiz; toplamda ise on üç hisse düzenlenmiştir. Her hissenin senede 500’lük Osmanlı altını faiziyle birlikte Osmanlı altını kârını mart ve eylül aylarında şirketin hazine sandığından zikrettiğimiz isimlere ödeme yapılması planlanmıştır. Bu isimlerden kalacak hisselerin öncelikle evlatlarına ${ }^{34}$, şayet çocukları yoksa üç kardeşten birbirine intikal etmesi kararlaştırılmıştır ${ }^{35}$. Süreç içerisinde birtakım sorunlar yaşandı̆̆ ${ }_{1}$ anlaşılmaktadır. Hisse senetlerinin kârları alınamayınca, konu ile ilgili olarak Agop Paşa görevlendirilmiştir ${ }^{36}$.

28 A. Osmanoğlu, a.g.e., s. 53; Fatmagül Demirel, Dolmabahçe ve Yıldız Saraylarında Son Ziyaretler, Son Ziyafetler, ed. Lütfü Tinç, Doğan Kitap, İstanbul 2007, s. 36.

29 BOA, Y.PRK.NMH, 4/47, lef 1-2. 11 Kânunuevvel 1889 (23 Aralık 1889).

30 BOA, Y.PRK.EŞA, 10/87, 20 Mart 1890.

31 Arzu Terzi, Bezmiâlem Valide Sultan, Timaş Yay., İstanbul 2018, s. 136-143.

32 BOA, Y.EE, 5/19, 26 Mayis 1306 (7 Haziran 1890).

33 BOA, Y.PRK.BŞK, 23/17, 13 Muharrem 1309 (19 Ağustos 1891).

34 Nâile Sultan'ın çocuğu olmamıştır. Uluçay, Padişahların Kadınları ve Kızları, s. 180.

35 BOA, Y.EE, 5/19, 26 Mayis 1306 (7 Haziran 1890).

36 BOA, Y.PRK.BŞK, 23/17, 7 Ağustos 1307 (19 Ağustos 1891). 
Şirket-i Hayriye hisse senetlerinden Nâime ve Nâile Sultanlar ile Şehzâde Burhaneddin Efendi’ye 6.500 kuruş altın, 13 tahvil, her bir adedi 152 Lira kıymetinde 1.976 Lira ayrılmıştır $^{37}$. Nâile Sultan'ın gelirleri arasında öncesinde Zekiye Sultan'a verilmiş sonrasında Nâile Sultan için ihsan buyrulan Küre Bakır Madeninden de bahsedebiliriz ${ }^{38}$.

Padişahın çocukları arasında hayatlarının sonuna kadar sıkıntı çekmeden yaşayan iki isim zikredilir: Nâile Sultan ve Burhaneddin Efendi. Bu iki isim ayrıca aile içerisinde, Sultan II. Abdülhamid'in en çok sevdiği çocukları olarak da bilinir. Sultan II. Abdülhamid'in saltanat yıllarında en fazla ihsân- ş̧ahâneye yine onlar sahip olmuşlardır. Bu sebepledir ki; menkul ve gayrimenkul birikimleri onların hayatlarının sonlarına kadar refah içinde yaşamalarına yardımcı olmuştur ${ }^{39}$.

\section{Saraya Damat Olmak}

Sarayda nikâh, soyun devamı olduğu kadar statü kazanımıdır. Saraya damat olmak prestijle birlikte sorumlulukları beraberinde getirmiştir ${ }^{40}$. Sultan II. Abdülhamid'in kızlarına damat seçerken titiz davrandığı, özellikle de eğitimli, asalet sahibi ve yakışıklı gençler olmasına özen gösterdiği bilinmektedir ${ }^{41}$. II. Abdülhamid kızı Nâile Sultan'ın izdivacını inşâ ederken ${ }^{42}$ damat seçimindeki öncelikli kriteri ne idi? Bu evlilik üzerinden konu ele alındığında, birkaç parametre meseleye yön vermektedir. İlk parametre damadın kim olacağı meselesi idi. Cemâleddin Bey ${ }^{43}$, Nâile Sultan için damat adayı olarak ismi zikredilen ilk kişi idi. Cemâleddin Bey’in ağabeylerinin Nâime ve Zekiye Sultanlarla yapmış oldukları olumsuz evlilikler sonrasında, Cemâleddin Bey damat adayı olarak uygun bulunmaz. Dolayısıyla Nâile Sultan'ın evliliğine değinmeden aslında onun da izdivacını etkileyen ablaları Nâime ve Zekiye sultanların eşleri üzerinde durulmalıdır ${ }^{44}$. Kemâleddin Paşa'nın

37 BOA, Y.PRK.ML, 28/76, lef 1, 14 Kânunusani 1323 (27 Ocak 1908).

38 BOA, Y.PRK.SGE, 11/37, lef 2, 14 Temmuz 1324 (27 Temmuz 1908); İstanbul'da Nâile Sultan ve eşi Arif Hikmet Paşa diğer tarafta İtalya Devleti tebasından İzak Fernandes tarafından imzalanan mukavelename içeriğine bakıldığında sürecin ne şekilde ilerlediği anlaşılmaktadır. BOA, HR.HMŞ.İ̧O, 128/1, lef 7; Kastamonu Vilayeti İnebolu Kazasına bağlı Küre Nâhiyesi'nde bulunan Küre bakır madeni hakkında Nâile Sultan ile Fernandes arasındaki ihtilaf 28 Mayıs 1920 tarihli takrir ile etraflıca incelenmiştir. BOA, HR.HMŞ. İŞO, 128/1 lef 3, 2 Ağustos 1338 (2 Ağustos 1922); Nâile Sultan 1880 ve 1881 yıllarında 75.000 kuruş maaş almaktadır. Cevdet Kırpık, Haremin Son Yüzyılı Sultanlar ve Damatlar, Timaş, İstanbul 2012, s. 223; Nâile Sultan'ın gerek evliliği öncesinde gerekse sonrasında biriken maaşlarının ödenmesi yönünde kaleme alınan evrak mevcuttur. BOA, HH.İ, 120/22, 8 Recep 1216 (22 Kasım 1898), BOA, HH.İ, 177/11, 6 Şubat 1320 (19 Şubat 1905).

39 Murat Bardakçı, Son Osmanlılar Osmanlı Hanedanı'nın Sürgün ve Miras Öyküsü, İnkılap, İstanbul 2007, s. 184.

40 Peirce, a.g.e., s. 89; Uzunçarş1lı, a.g.e., s. 163-164; Uluçay, Harem II, s. 91-92.

41 Uluçay, Harem II, s.91-92.

42 A. Osmanoğlu, a.g.e., s. 69-70.

43 Plevne kahramanı Gazi Osman Paşa’nın oğullarından. M. Metin Hülagü, "Gazi Osman Paşa”, DİA, c. XIII, s. 464-465.

44 A. Osmanoğlu, a.g.e., s. 69-70. 
Nâime Sultan ile izdivacının padişahın baskısıyla bittiği söylenmektedir ${ }^{45}$. Nureddin Paşa ise Zekiye Sultan'ın eşi idi ${ }^{4}$. Nureddin Paşa, eğlence ve lükse düşkün bir isimdi. Paşa'nın, İstanbul'un eğlence mekânları arasında sayılan Beyoğlu ve Kağıthane gezintileri meşhurdu. Dahası paşa, çapkınlığı ile de tanıtılmakta idi. O kadar ki; bu havâi tavırlar paşa hakkında birçok dedikoduyu beraberinde getirmiştir. Basına yansıyan haberlerle paşanın hovardalığı gündemi işgal etmiş ve gönül ilişkileri dillendirilmiştir ${ }^{47}$.

Cemâleddin Bey damat olarak seçilmeyince, ibrenin yönü Arif Hikmet Bey (1871/721942)'e kaymıştır. Nâile Sultan ile Arif Hikmet Bey'in izdivacı nasıl inşâ edilmiştir? Evrak dilinde, damat seçiminde önemli bir kriter mehâsin kelimesi dikkatimizi çekmektedir. Kelime anlamı olarak göze hitap eden güzelliklerin yanı sıra iyilikler, manevi güzellikler, iyi ve güzel davranışlar anlamına gelen bu kelime özellikle damat seçiminde önceliğin hangi meziyet olduğuyla alakalı ipucu vermektedir. Damadın evsâf-ı güzîde ifadesiyle anlatılması onun nasıl bir kişi olduğunun ve çevresi tarafından nasıl tanındığının önemsenmesiyle ilişkilidir. Bu özelliklerini referans aldığı düşünülen damadın babası, terbiyet-i peder olarak zikredilir. Böylece Arif Hikmet Bey'in yetiştirilirken babasından almış olduğu terbiyeye vurgu yapılmıştır ${ }^{48}$.

Sultan II. Abdülhamid'in en sevdiği damadı olarak tanınan Arif Hikmet Paşa'nın babasından sonra sadrazamlığa hazırlandığı söylenmektedir. Halid Ziya Uşaklıgil, gelini ve damadı şu sözlerle anlatır: “...Onun tâliine (talihine) Abdülhamid’in pek vakur (ăğr başlı), pek ciddi bir fitrat (yaradılış) sahibi olan kızı Nâile Sultan isâbet etmişti. Kendisi de mensup olduğu ailenin asaletinden ve babasının devrettiği nezâhetinden (temizliğinden) bir nebze (parça) kaybetmemiş olduğu için, bu izdivaçlar içinde onunkine pek iyi bir numûne (örnek) olarak bakmak mümkündür..."49

Damadın babasının kim olacağı meselesi ile konuya yaklaşıldığında ise Örik, II. Abdülhamid'in kızlarına damat seçerken onların babalarını memnun etmenin önemli olduğu üzerinde durmuştur ${ }^{50}$. Nâile Sultan'a damat seçilen Arif Hikmet Paşa'nın babası Sadrazam ve

45 Sara Ertuğrul, Geçmiş Zaman Olur ki..., anlatan Mevhive Celâlettin, M. Sıralar Matbaası, İstanbul 1953, s. 79; Uluçay, Harem II, s. 92.

46 Düğünü 1889 tarihinde gerçekleşen Nureddin Paşa, diğer damatlar gibi Maliye Hazinesi'nden 9.000 kuruş sıhriyyet maaşı almıştır. Bu miktar düğünden bir sene sonra 15.000 kuruşa çıkarılmıştır. Cevriye Uru, Sultan II. Abdülhamid'in Kızı Zekiye Sultan'ın Hayatı (1872-1950), Marmara Üniversitesi Türkiyat Araştırmaları Enstitüsü Türk Tarihi Anabilim Dalı Yakınçağ Tarihi Bilim Dalı, Yayınlanmamış Yüksek Lisans Tezi, İstanbul 2010, s. 28-29.

47 Uru, a.g.t., s. 16-20; BOA, Y.PRK.UM, 34/119, 29 Nisan 1312 (11 May1s 1896).

48 BOA, Y.PRK.MŞ, 8/10, lef 6, 5 Şubat 1320 (18 Şubat 1905).

49 Halit Ziya Uşaklıgil, Saray ve Ötesi Anılar, yay. haz. Nur Özmel Akın, Özgür Yayınları, İstanbul 2003, s. 235236.

50 Örik, Saraylılar, s. 18, 31; Haluk Y. Şehsüvaroğlu, "Plevne Müdafii Gazi Müşir Osman Paşa”, Resimli Tarih Mecmuası, sayı 21, İstanbul 1951, s. 937-940. 
Adliye Nazırı Abdurrahman Paşa ${ }^{51}$ (1835-1941), Sultan II. Abdülhamid'in başarılı bulduğu bir isimdi ${ }^{52}$. Damadın babasının özellikleri de Nâile Sultan ile Arif Hikmet Paşa’nın evliliklerine olumlu yaklaşılmasına zemin hazırlamıştır. Sonuç olarak bu izdivaçta, Nâile Sultan'ın rızası çerçevesinde hareket edilmiş ve bu emr-i hayrın her iki tarafa saadet ve mutluluk getirmesi temennisinde bulunulmuştur ${ }^{53}$.

\section{Arif Hikmet Bey'den Damat Arif Hikmet Paşa'ya}

Hanedan evliliklerinde kendilerine çizilmiş alan ve imkân çerçevesinde hareket eden damat, eşinin vasıtasıyla kendi nüfûzunu şekillendirmiştir. Damat, iktidar alanının içinde bulunmakla birlikte yerini ve konumunu bilmesi gereken bir sınırda tutulmaktadır. Sultanın evlilik inşâsında ortaya konulan olanaklar, damadı bağlamaktadır. Nikâh sonrasında damat gücünü bir yönüyle de sultandan almaktadır. Bu sebeple, damadın hayatının nasıl etkilendiğinin anlaşılması bakımından terfiler, görevler ve maaşlar dikkate alınmalıdır. Bu bakış açısıyla, damadın hayat standartlarındaki değişimin izinin sürülmesinin konuya katkı sağlayacağı düşünülmektedir. Öncelikle padişah kızı, maddi olarak damat karşısında güçlü durmaktadır. Sultanın maaşı, damattan daha yüksektir. Padişah tarafından tahsis edilen saray sultana aittir ve damat sarayda herhangi bir hak iddia edemez. Damadın tek eşlilik mecburiyeti, odalık temin edememesi sultanı korumaya yöneliktir. Damat, nişan ya da evlilik sonrasında hanedan mensubu olmaları itibariyle yüksek rütbelere terfi ettirilmiştir. $\mathrm{Bu}$ yeni konumun onun hem maaşına hem de toplum içerisindeki saygınlığına olumlu etkileri olmuştur. Diğer taraftan, damatlık anlayışı içerisinde kimi zaman lüks hayata meyletme yer etse de sürgün, tecrit, idam gibi cezaların unutulmaması gerekir ${ }^{54}$.

II. Meşrutiyet öncesinde damatlar için tercih edilen mevki olarak Şûrâ-yı Devlet'in çeşitli daireleri karşımıza çıkmaktadır. Cevdet Kırpık, II.Abdülhamid'in saltanat yıllarında onaylanan damatların hemen hemen hepsinin Şûrâ-yı Devlet üyeliğine atandığını söylemektedir ${ }^{55}$. II. Abdülhamid döneminde subay kökenli damatların terfilerinde bir standart uygulamaya rastlanılmamış, diğer taraftan sivil damatlar kadar çabuk yükselmediklerine vurgu yapılmıştır. Bu anlamda askeri prosedürün göz ardı edilmediğinin altı çizilmelidir ${ }^{56}$. Rütbe, makam ve mevkinin yanı sıra damatlar maaş almışlardır: Sıhriyet ${ }^{57}$ maaşı. Bu, damatların vazifeleri gereği almış oldukları maaşlarla birlikte, evliliğin padişah tarafından resmen

51 Abdurrahman Paşa (Abdurrahman Nureddin Paşa) hakkında detaylı bilgi bkz. Mehmed Zeki Pakalın, Sicilli Osmanî Zeyli, yay. haz. Gülbadi Alan, TTK Yay., Ankara 2008, c. I, s. 59-64.

52 Kirpık, Haremin Son Yüzyılı, s. 56.

53 BOA, Y.PRK.MŞ, 8/10, lef 6, 5 Şubat 1320 (18 Şubat 1905).

54 Alderson, a.g.e., s. 155; Uzunçarş1lı, a.g.e., s. 163-164; Uluçay, Harem II, s. 91-92; Kırpık, a.g.e., s. $322-323$.

55 Arif Hikmet ve Mehmet Şerif Paşalar gibi damat olduklarında Şûrâ-yı Devlet’te çalışan isimler de bulunmaktadir.

56 Kirp1k, a.g.e., s. 267, 293-294.

57 Fikhî terim olarak sıhriyet evlilik sebebiyle meydana gelen hısımlıktır. Detaylı bilgi için bkz. Hamza Aktan, "Sihriyet", DIA, c. XXXVII, s. 111-112. 
onaylanmasıyla onlara bağlanan damatlık maaşıdır. Prosedür gereği sıhriyet maaş miktarı, padişahın emriyle belirlenmiştir. Bu şekilde sıhriyet-i seniyye tertibinden damatlık maaşları bütçede gösterilmiştir. Damatların çoğunluğu memur olduklarından, bu vazife dolayısıyla memuriyet maaşları da bulunmaktadır. Bazen bu iki maaş birleştirilip, tek maaş şeklinde ödeme yapılmıştır ${ }^{58}$. Sihriyet maaşını, damadın taçlandırılması olarak ifade edebiliriz.

Nâile Sultan'la evlenen oğlu Arif Hikmet Paşa, 1871/1872 yılında Prizren'de dünyaya gelmiştir. Evlilik öncesi memuriyetlerine bakıldığında, öncelikle 1892 yılında Aydın vilâyeti maiyet memurluğu vazifesini yerine getirdiği görülmektedir. Sonrasında Şûrâ-yı Devlet azalığına tayin olmuştur. Nâile Sultan ile evlenen Arif Hikmet Bey artık vezirdir ${ }^{59}$. Bu süreç, damadın terfi edebilmesinin yolunu açarken öncelikle Nâile Sultan'ın maaşının, Zekiye Sultan'ın maaşına muadil bir seviyeye getirilmesi bildirilmiştir ${ }^{60}$. 1904 yılı kayıtlarına bakıldığında, Zekiye Sultan'ın maaşının 80.000 kuruş olduğunu görmekteyiz ${ }^{61}$. Padişah kızları arasında yapılan maaş düzenlemesi sonrasında damat için uygun görülen prosedür de devreye girmiştir. Akabinde damada maaş tahsis edilmiştir ${ }^{62}$. Dügüunden çok kısa bir sonra yani Mart 1905 tarihi itibariyle, damada memuriyet ücretinin yanı sıra Mâliye Hazinesi'nden emsâl-i vech 12.500 kuruş maaş bağlanmıştır ${ }^{63}$. Tarihler Ocak 1906'yı gösterdiğinde ise Damat Arif Hikmet Paşa'nın 6.000 kuruşluk maaş1 9.000 kuruş zam ile 15.000 kuruşa yükseltilmiştir ${ }^{64}$.

58 Kirpik, a.g.e, s. 267, 293-294.

59 Pakalın, Sicill-i Osmanî Zeyli, c. III, s. 106-108.

60 BOA, BEO, 2520/188978, lef 1, 23 Şubat 1320 (8 Mart 1905).

61 BOA, BEO, 2337/175221, 29 Mart 1320 (11 Nisan 1904); Sultan maaşlarını etkileyen faktörler arasında medeni durum, babasının sağ olması ve babası ile olan ilişkiler sayılabilir. Kırpık, a.g.e., s. 217.

62 BOA, BEO, 2520/188978, lef 1, 23 Şubat 1320 (8 Mart 1905).

63 BOA, ŞD, 3195/157 10 Mart 1321 (23 Mart 1905).

64 BOA, ŞD, 3196/28, 13 Kânunusani 1321 (26 Ocak 1906); Evliliği sonrasında Damat Arif Hikmet Paşa'nın maaşı hakkında; Paşa'nın, 15 Kânunusani 1321 (28 Ocak 1906) tarihinden itibaren 15.000 kuruşa çıkarılması kaydı icra kılınmıştır. BOA, DH.MKT, 1048/43 lef 1, 29 Kânunusani 1321 (11 Şubat 1906). Evliliğin üçüncü yılına gelindiğinde Arif Hikmet Paşa'nın maaş düzenlemesinin diğer damatların maaşları göz önünde bulundurularak ayarlandığını ifade edebiliriz. 25 Ağustos 1908 tarihli Mâliye Nezâreti’ne gönderilmiş olan tezkirenin cevabında, memuriyet-i mülkiyelerinden dolayı maaşı araştırılan Damat Arif Hikmet Paşa'nın nezaretçe maaşı bulunmayıp, sadece 15.000 kuruş maaşı olduğu açıklanmıştır. BOA, DH.MKT, 1289/20, lef 2, 20 Ağustos 1324 (2 Eylül 1908); Damatlar Nureddin, Ahmed, Halid, Mehmed, Ferîk Salih ve Arif Hikmet Paşaların sıhriyete göre dahiliye ve nizâmiye tahsîsatı çerçevesinde almakta oldukları maaşların aynı olması lüzumu bildirilmiştir. BOA, İ.DUİT, 3/5, 10 Eylül 1324 (23 Eylül 1908). Sultan II. Abdülhamid tahttan indirildikten sonraki döneme göz atıldığında eski Şûrâ-yı devlet azâsı olan Damat Arif Hikmet Paşa tarafından verilen dilekçede, kendisine sıhriyet maaşı tahsis edilmediği ve mağduriyet yaşadığı belirtilmiştir. Tazminât-l nakdiye talebinde mecburiyet hasıl olunca Tensîkat Kanunu'nun dokuzuncu maddesi gereğince hak ettiği 1.000 Liranın ödenmesi talebinde bulunmuştur. Gerçekleştirilen düzenlemede mâzûliyet maaşı tahsis edilmek üzere açığa çıkarılan memurların tazminat alarak hükümetle alâkaları kesilmiştir. Gerekli tazminatın ödenmesi tabii ise de Arif Hikmet Paşa'nın vazifelerinde liyakat sahibi olması, işindeki başarısı ve tecrübesinden istifade edilmesi gerektiği göz önünde bulundurularak tayini istenmiştir. Damadın Şûrâ-yı devlet azalığı ile riyâset- $i$ saniyedeki başarısı ifade edilmiştir. BOA, BEO, 3657/274214, lef 2, 13 Teşrinievvel 1325 (26 Ekim 1909); Damat Arif Hikmet Paşa'nın devlet tarafından istifade edilebilecek bir isim olması hasebiyle bu duruma mani olacak bir muamelede bulunulmaması bildirilmiştir. BOA, BEO, 3657/274214, lef 1, 19 Teşrinievvel 1325 


\begin{tabular}{|l|l|l|}
\hline \multicolumn{3}{|l|}{ Tablo 1: Damat Arif Hikmet Paşa ve Diğer Damatların Almış Oldukları Maaşlar ${ }^{65}$} \\
\hline Sıhriyyet Maaşı (kuruş) & Memuriyet Maaşı (kuruş) & İsim \\
\hline 15.000 & 16.704 & Damat Müşir Nûreddin Paşa \\
\hline 15.000 & 16.704 & Damat Ahmed Paşa \\
\hline 15.000 & 16.704 & Damat Hâlid Paşa \\
\hline 9.000 & 16.704 & Damat Mehmed Paşa \\
\hline 10.000 & 7.579 & Damat Ferik Salih Paşa \\
\hline 12.500 & 15.000 & Damat Arif Hikmet Paşa \\
\hline $\mathbf{7 6 . 5 0 0}$ & $\mathbf{8 9 . 3 9 7}$ & Toplam \\
\hline
\end{tabular}

\section{Maddi Kültür Değerleri Yönünden Nâile Sultan'ın Düğün Hazırlıkları}

Arapça kökenli bir kelime olan çeyiz/cehâz kelimesinin sözlük anlamlarından birisi gelinin pederi, evinden kocası evine beraberinde getirdiği elbise, eşya ve takımlardır ${ }^{66}$. Osmanlı toplum yaşantısı içinde kız evlat için hazırlanan çeyizin kıymetli bir yeri vardır. Çeyiz bir anlamda ailenin gücünün göstergesidir ${ }^{67}$. Gelin, hanedan mensubu ise bu ihtişam daha da ön plana çıkmaktadır. Geline takılan mücevherlerden kıyafetlere, gündelik kullanılacak eşyalardan, hediyelere kadar hassasiyetle yaklaşılmıştır. Düğün hazırlıklarında çeyiz öncelikli mevzû görüldüğü için kısa zamanda özenle hazırlıkları tamamlamak üzere Hazîne-i Hâssa dahilinde bir komisyon teşkil edilmiştir ${ }^{68}$.

Sultan düğünlerinde kıyafet konusuna, kumaşın cinsinden rengine kadar itina ile yaklaşılmıştır. II. Abdülhamid'in kızlarından Nâime Sultan, gelin kıyafeti olarak hanedan hanımlarının giydikleri koyu kırmızı renkli kostümü tercih etmez. Avrupa modasının uzantısı sayılan beyaz elbise giymiştir. Nâime Sultan'ın saray düğünlerinde beyaz

(1 Kasım 1909); Damat Arif Hikmet Paşa’ya Adliye Nezâreti'nden bildirilen malumatta, mazûliyyet maaşı tahsis edildiği ve kendisinin önceden almakta olduğu 3.000 kuruş sthriyyet maaşına bütçe çerçevesinde alıkonulduğu açıklanmıştır. BOA, BEO, 4216/316199, 12 Eylül 1329 (25 Eylül 1913); Damat Arif Hikmet Paşa 16 Ekim 1912'de Kamil Paşa tarafından kurulan kabinede Adliye Nâzırı ve Şûrâ-yı Devlet başkan vekili olarak karşımıza çıkar. 25 Şubat 1918'de Adliye Nâzırı olarak Tevfik Paşa kabinesinde yer almaktadır. Pakalın, Sicill-i Osmanî Zeyli, c. III, s. 106-108; 13 Ocak 1919 tarihli Sadrazam Tevfik Paşa'nın idaresindeki heyette Adliye Nezâreti Başkanı olarak Arif Hikmet Paşa'nın ismi geçmektedir. BOA, DUİT, 9/52, 13 Kânunusani 1335 (13 Ocak 1919); Mart 1919'da görevinden istifa ederek ayan azalığı vazifesini üstlenmiştir. 1920 yılında ikinci defa Adliye Nâzırı olarak karşımıza çıkan Arif Hikmet Paşa, Maârif Nâzırı olarak da çalışmıştır. 1921 senesinde istifası sonrasında 2 Mart 1924'te hilâfetin ilgası kanunu üzerine saltanat hanedanı mensubu olması dolayısıyla hudut haricine çıkarılan isimler arasındadır. Pakalın, Sicill-i Osmanî Zeyli, c. III, s. 106-108.

65 BOA, İ.DUİT, 3/3, 6 Nisan 1324 (19 Nisan 1908).

66 Sâmi, "Cehâz", a.g.e., s. 488.

67 Abdülaziz Bey, Osmanlı Adet, Merasim ve Tabirleri, I, Tarih Vakfi Yurt Yayınları, İstanbul 1995, s. 1; Uzunçarş1lı, a.g.e., s. 161-164; Uluçay, Harem II, s. 96.

68 BOA, Y.MTV, 279/32, 9 Haziran 1321( 22 Haziran 1905); mücevherât: 740.000 kuruş, atiyye: 301.000 kuruş, avâid: 34.500 kuruş, takdim: 65.000 kuruş, avâni: 147.722 kuruş, nişan takımı: 37.022 kuruş, hediyeler: 284.658 kuruş, melbûsât: 136.209 kuruş, tefrişât: 390.382 kuruş, levâzım-1 beytiyye:80.947 kuruş, tamir: 70.342 kuruş, yatak takımları: 50.077 kuruş, kiler mutfak takımları: 33.935 kuruş, saraya alınan sobalar: 28.440 kuruş, seccâde abdest takımları: 7.573 kuruş, damat beyin eşyaları: 10. 436 kuruş, perakende: 15.071 kuruş, ziyâfet: 48.766 kuruş toplamda ise 2. 482.080 kuruş. BOA., Y.PRK. KOM. nr.16/13 lef 1, 27 Kânunuevvel 1323 (9 Ocak 1908). 
elbise giyen ilk isim olduğunun altını çizilir ${ }^{69}$. O devir için çok da alışı olunmayan bu durum hoş karşılanmadığı gibi, elbisenin beyaz renkte olmasını tenkit edenlerin olduğu söylenmektedir ${ }^{70}$. Nâile Sultan'ın duvağı, entarileri, kürkü ve iskarpini işlemelidir. İşleme sultanın bütün kıyafetlerinde kendisini göstermiştir. Nâile Sultan'ın çeyizindeki işlemelerde Sırmacı Mıgırdiç Ağa'nın emeği vardır. İnci sultanın kıyafetlerinde tercih edilmiş başka bir detaydır. Nâile Sultan'ın beyaz elbisesi, kürkü, iskarpini ve duvağı inciyle bezenmiştir ${ }^{71}$. Burada Madam Ephigénie Epenetos'un isminin zikredilmesi gerekir ${ }^{72}$. Sultanın ipekli beyaz uzun etekli fistanlık-iskarpin ${ }^{73}$; mavi fistanlık-mavi iskarpin; pembe ipekli fistanlık-iskarpin; eflatun fistanlık-iskarpin takımlarının dikişlerinde bu hanımefendinin imzası vardır ${ }^{74}$. Madam Ephigénie, sultanın birinci ve ikinci günlerde giyeceği elbisesinin arka uzun eteği, ön eteği, dantel, beden ve kol kısımlarında sırma işleme kullanmıştır. Resm günü için sultanın tercih ettiği beyaz atlasla kaplanmış kürkün ön ve arka kısımları olduğu gibi ve duvağında işleme detayları dikkat çekicidir ${ }^{75}$. Sultanefendinin kreasyonunda beyaz, mavi, pembe ve eflatun renkler tercih edilmiştir. Nâile Sultan'ın elbiseleri ve ayakkabıları takım olarak hazırlanmıştır. Sultanın kıyafetlerinin astarları beyaz, mavi, pembe, kayısı rengi ve krem taftalardır. İpekçi Kani Efendi Mağazası'ndan eflatun ve krem rengi saten siparişleri verilmiştir ${ }^{76}$.

Nâile Sultan kıyafetlerini, büyük pırlanta tek taş altın yüzük, etrafı büyük altın taşlarla bezeli küpe, etrafı büyük-orta altın taşlarla çevrili bilezik, büyük-orta altın taşlar ve pırlanta ufak taşlarla süslenmiş taç ${ }^{77}$ tamamlamıştır. Evlilik adetleri içerisinde, kız evinden damada kıyafet bohçası içerisine kürk koymak bir adettir. Sadece kış aylarında değil yazın da serin ve soğuk havalarda tercih edilen kürklerin muhafazası için özel kürk bohçaları bulunmaktadır ${ }^{78}$. Nâile Sultan'ın giymiş olduğu kürkler arasında vaşak tespit edilmiştił ${ }^{79}$. Kürkçübaşıâde Mehmed Ali Bey’den de 3.200 kuruşa satın alınan kürklere kürk sırrı kaplatmak için tutulan ustalar çalıştırılmıştır ${ }^{80}$. Sultanefendinin kürk kapları, bal rengi ve lacivert olarak tasarlanmıştır ${ }^{81}$.

69 Bağçe, a.g.t., s. 47; Ayşe Osmanoğlu hatıralarında, Nâime Sultan'ın gelin kıyafetinin uzun olduğundan, yerlere kadar değdiğinden ve dört etekli olduğundan bahseder. Elbisenin önü göğsünden aşağıya kadar pırlantalı düğmelerle bezelidir. Belindeki kemer mücevher tokalıdır. Bu giysiyi omuzlarından arka eteklerine uzanan inci ve sıra ile işlemeli kürk tamamlar. Nâime Sultan’ın, düğün elbisesindeki renk tercihi o zamana kadar kullanılmamış beyaz renktir. A. Osmanoğlu, a.g.e., s. 69-71.

70 Uluçay, Harem II, s. 112.

71 BOA, HH.d, 5947, 9 Haziran 1321 (22 Haziran 1905), s. 1-24.

72 Ephigénie Epenetos'un işleme işyeri Beyoğlu’nda İngiliz Eczahanesi’nin karşısında 190 numaralı mekândır. BOA, HH.d, 5947, 31 Kânunusani 1320 (13 Şubat 1905), s. 1.

73 İskarpin: Ökçeli, ayağın oynak yerini kapamayan konçsuz ayakkabı.

74 BOA, MB, 1036/23, lef 2, 5 Mart 1321 (18 Mart 1905).

75 BOA, HH.d, 6486, 11 Şubat 1320 (24 Şubat 1905), s. 1.

76 BOA, HH.d, 6487, 28 Şubat 1320 (13 Mart 1905), s. 1-13.

77 BOA, MB, 1036/19, lef 1, 15 Şubat 1320 (28 Şubat 1905); BOA, MB, 1036/19, lef 5, 23 Şubat 1321 (8 Mart 1906).

78 Filiz Karaca, "Kürk”, DİA, c. XXVI, s. 568-570.

79 BOA, HH.d, 6487, 5 Şubat 1320 (18 Şubat 1905), s. 2.

80 Ustalara yevmiye olarak 625 kuruş olarak ödenmiştir. BOA, HH.d, 5947, 12 Şubat 1320, s. 7.

81 BOA, HH.d, 6487, 28 Şubat 1320 (13 Mart 1905), s. 1-13. 
Nâile Sultan'ın levâzım-ı cihâziyesi içerisinde damat için kolalı keten Frenk gömleği ${ }^{82}$, siyah boyun bağı-ipek boyun bağı, yün ipek çorap ${ }^{83}$, ipek fanila ve don siparişleri verilmiştir ${ }^{84}$. Yine Beyoğlu'nda Kostaki Mağazası'ndan damat için pazen don ve keten çorap satın alınmıştır ${ }^{85}$. Damadın kürkünde de Madam Ephigénie'nin imzası vardır ${ }^{86}$. Meşin kılıf içerisinde ustura takımları, sim berber leğeni-berber tası hazırlanmıştır ${ }^{87}$. Damadın ustura takımı Beyoğlu'nda Bekir Mağazası'ndan satın alınken ${ }^{88}$, Hereke Fabrikası'ndan da alışveriş yapılmıştır ${ }^{89}$. Nâile Sultan'ın yatak-seccade-hamam-abdest takımları sırma ve inciyle işlenmiştir. Yatak takımlarında, seccade-abdest, hamam takımlarında astarlık atlas kumaş kullanılmıştır ${ }^{90}$. Keten çarşaf, yastık yorgandan oluşan beyaz yatak takımlarının işlemesini Madam Ephigénie yapmıştır $^{91}$. Dantel işlemeli beyaz ${ }^{92}$ ve pembe atlas yorgan sultanın çeyizine konulmuştur ${ }^{93}$. Takım, pembe renkte uzun yan, baş ve dört köşe yastıklar ve yastık başından oluşmaktadır ${ }^{94}$. İncinin sultanın çeyizinde önemli bir yeri olduğundan bahsetmiştik. Kıyafetlerinden gündelik kullanılan mefruşata yorgan-çarşaf-yastık, kahve örtüsü, seccade ve fes örtüsüne inciyle süslenmiştir. Nişan takımları, fes örtüsü, seccade-abdest-hamam takımları, kahve, leğen ve çaşnigir örtüleri de sırma-tırtıl ile bezenmiştir ${ }^{95}$. Kahve-çaşnigir ve leğen örtüsü de incidir ${ }^{96}$. Renk tercihlerine bakıldığında yatak takımları içerisinde sırma işlemeli gelin yorganı krem rengidir. Takım içerisinde sırma işlemeli baş yastı $\breve{g}_{1}{ }^{97}$, uzun karyola yastı $\breve{g}_{1}$, dört köşe yastıklar ${ }^{98}$ da krem rengidir. Gelin yorganı ve yastıkları için pembe saten uygun görülmüştür ${ }^{99}$.

Nâile Sultan'ın çeyizine koyulan kıymetli sofra eşyaları arasında Kaşıkçılar Kethüdası Ali Efendi'den satın alınmış olan uçları mercanlı fil dişiden sapı bağadan imal edilmiş hoşaf ${ }^{100}$ ve tatlı kaşıklarıyla uçları mercanlı fil dişi yemek kaşıkları vardır ${ }^{101}$. Levâzım-ı cihâziye için alışveriş yapılan esnaf arasında Kaşıkçılar Kethüdasi Ali Efendi’nin ismi geçer ${ }^{102}$. Yemek-

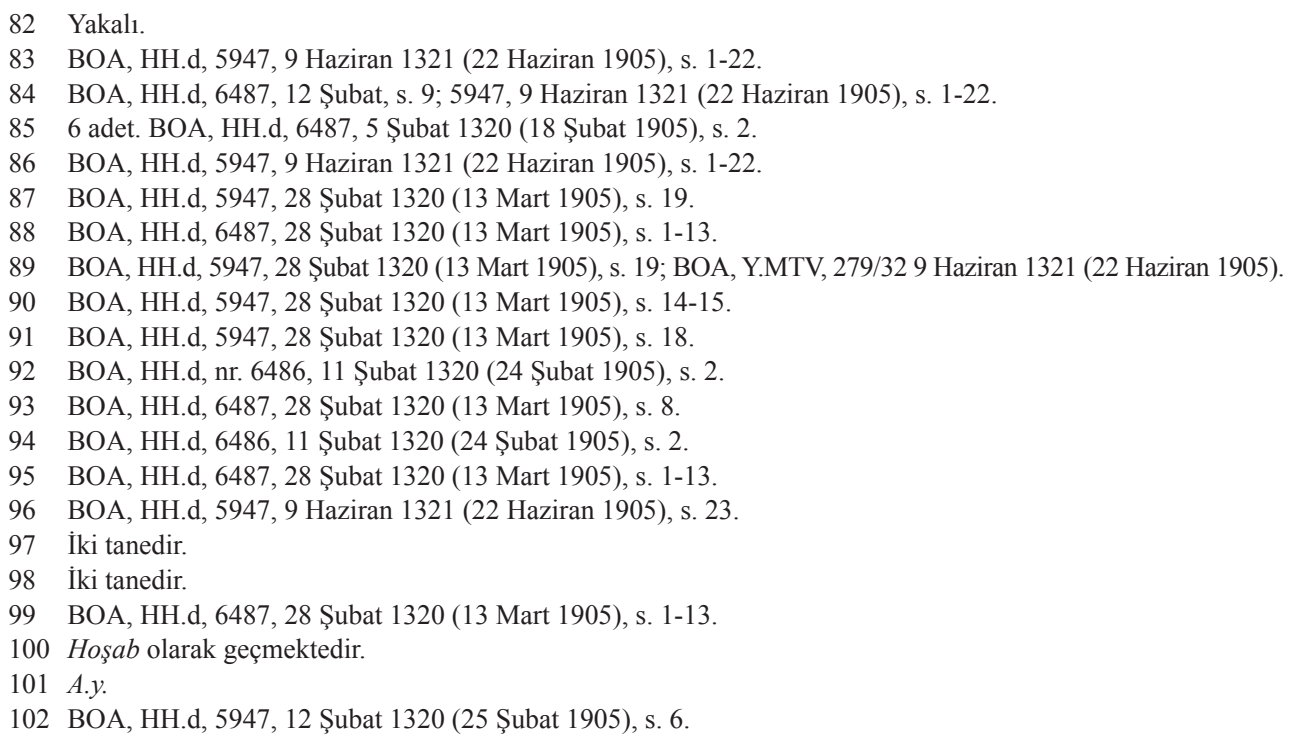


çay-kahve takımları, kase-testi-ibrik-kap ve kacaklarının gümüşleri Çarşı-yı Kebîrde Mahmûd Paşa Hanı'nda Cilaciyan tarafından hazırlanmıştır ${ }^{103}$. Beyaz-sarı sırma işlemeli sofra altlıkları satın alınmıştı1 ${ }^{104}$. Osmanlı mutfağında sıklıkla görülen bakır kap-kaçak Nâile Sultan'ın cihaz takımı için de tedarik edilmiştir. Bunların arasında sebze için bakır sahan, bakır pilav-kuzu lengeri; temel mutfak kapları içerisinde sahan, tencere ve kazan yer alır. Bakır tabaklar yassı ve çukur olmasının yanı sıra, kahvaltı tabağı, reçel tabağı, salata tabakları olarak çeyize yerleştirilmiştir. Kapaklı hoşaf kaseleri bakır ve billurdur. Pilav lengeri ${ }^{105}$ bakır, kuzu lengeri ise yayvan ve derinliği az tercih edilmiştir. Kullanım amacına göre büyük-küçük ya da kenarlı ve yemek tepsileri seçilirken, mutfak için boyalı-yaldızlı kapağı olan sahanlar, kapaklı kaseler, siniler ve kuşhaneler ${ }^{106}$ sipariş edilmiştir.

Aşurelikleri, saray yaşamında geleneksel maddi kültür objeler olarak görülebilir. Sarayda hazırlanan aşureler, genellikle porselen tek kulplu aşure testisi adı verilen kaplarda servis edilmiştir ${ }^{107}$. Çeyiz için beş adet yaldızlı aşure testisiyle birlikte on adet yaldızlı aşure bardağıtabak ve kapağı satın alınmıştır. İnce ayaklı ve yaldızlı Fransızkârî bardaklar kıymetli mutfak eşyaları arasında göze çarpmaktadır ${ }^{108}$. Fransızkârî kristal su takımı ve Fransızkârî kristal su bardakları için Cezerney Mağazası tercih edilmiştir. Büyük ve orta ebatlarda kristal su takımları bulunmaktadır ${ }^{109}$. Fransızkârî yaldızlı kahve fincan takımının yanı sıra âla elmas gibi yontulmuş su takımları özenle seçilmiştir ${ }^{110}$. Sitil pûşîdesi, sarayda kahve sunumunda kullanılan kahve tepsisinin ve sitil takımının önemli bir tamamlayıcısıdır. Kahve ikramında fincanlar zarflar içerisinde tepsiye yerleştirilirken, tepsinin ön tarafından sarkan sitil pûşîdesi bir anlamda servisi yapan vazifeli için bir önlük işlevi görmektedir ${ }^{111}$. Kahve sunumları için kullanılan kahve fincanları ev sahibinin maddi gücünün göstergesi olmasının yanında misafire verilen kıymete işaret etmektedir. Kahve sunumlarında ikramı içen kişinin elinin yanmaması için zarflar kullanılmıştır. Fincan zarflarına zarafet katan değerli taşlardı1 ${ }^{112}$. Nâile Sultan'ın çeyizinde kahve tepsisinin etrafina konulmak üzere kahve pûşîdesi ve saçaklı kahve örtü unutulmamıştır. Kahve pûşîdesi sırma kahve örtüsü ise inciyle ${ }^{113}$ bezenmiştir. Fransızkârî yaldızlı kahve fincanı ve takımlar dikkat çekmektedir ${ }^{114}$. İkramlar, İngiliz yapımı gümüş kaplama büyük-orta şerbet ve küçük kahve tepsilerinde yapılmıştır. Süslemeler için seramik

103 BOA, HH.d, 5947, 1 Şubat 1320 (14 Şubat 1905), s. 1.

104 BOA, HH.d, 6487, 12 Şubat 1320 (15 Şubat 1905), s. 10.

105 Lenger: Büyük yayvan kenarları geniş bakı yemek kabı.

106 BOA, HH.d, 24342, 15 Şubat 1320 (28 Şubat 1905), s. 15.

107 Terzi, Bezmiâlem Valide Sultan, s. 180.

108 BOA, HH.d, 24342, 15 Şubat 1320 (28 Şubat 1905), s. 15.

109 BOA, HH.d, 24342, 15 Şubat 1320 (28 Şubat 1905), s. 35.

110 BOA, MB, 1036/17, lef 119 Şubat 1320 (4 Mart 1905).

111 Terzi, Bezmiâlem Valide Sultan, s. 184.

112 Abdülaziz Bey, Osmanl Adet, Merasim ve Tabirleri, s. 210-211.

113 BOA, HH.d, 6487, 28 Şubat 1320 (13 Mart 1905), s. 10-13.

114 BOA, HH.d, 24342, 15 Şubat 1320 (28 Şubat 1905), s. 35. 
malzemeden imal edilmiş Majolik ${ }^{115}$ çiçek takımı, Fransızkârî çiçeklik tercih edilmiştir ${ }^{116}$. Düğün kışa geldiği için çeyizde Nâile Sultan’ın dairesine konulmak üzere sobalar ve pirinç mangallar da yer almıştır ${ }^{117}$. Aydınlatmada elvan renkli fitilli kısa Majolik kırmızı-tirşe ${ }^{118}$ ve billur pembe lambalarla birlikte 24 ve 12 mumlu billur avizelerden ${ }^{119}$ istifade edilmiştir.

II. Abdülhamid'in saltanat yıllarında dügüülerde hediye alıp verme usulünün kaldırılmasının gerekliliğini ifade eden açıklamaları dönem basınından okunmaktayız. Basına yansıdığı kadarıyla, sultanların akd-i velîmelerinde çeşitli masrafların yapılmaktadır, dahası bu masrafların çokluğu ve adet haline alınmasından rahatsızlık duyulmaktadır ${ }^{120}$. Diğer taraftan Nâile Sultan'ın düğün hazırlıklarına bakıldığında, atiye ve hediyenin önemli bir yeri olduğunu düşünmekteyiz. Nâile Sultan'ın düğün masraflarını gösteren defterde hediyeden bahsedilmiştir. Nâile Sultan için istenen mücevherin yanı sıra bazı isimlere hediye edilmek üzere de mücevher alınmış ${ }^{121}$ ve atiye olarak 301.000 kuruş ayrılmıştır ${ }^{122}$. Nâile Sultan'ın levâzım-ı cihâziyelerinden hediye-i seniyye olarak ayrıca takdim olunan bazı murassa $^{6123}$ kutular ve eşyalar satın alınmıştır. Nişan takımları arasında damat için on bir karatlık tek taş pırlanta kravat iğnesi, murassa' büyük pırlanta düğme takımı yer almaktadır. Yine hediye-i seniyye olarak kayıt edilen bir çift incili elmaslı düğme takımı, incili murassa“ göğüs iğnesinden bahsedebiliriz. Beş çift büyük murassa d düğme, bunlara ilave olarak elli çift olmak üzere murassa' gül resminde düğme, tek taş düğme sipariş edilmiştir ${ }^{124}$. Padişah adına sunulan hediyelerin mevcudiyeti bizi dügünlerde bu usulün tamamen kaldırılmadığ bilgisine götürmektedir.

Sultanefendi'nin çeyizlerinin konulup taşınmasında kullanılan sandıklar, maun ve ceviz kaplama olmasının yanı sıra kulpları nikeldir. Dört adet büyük maun sandığın menteşeleri pirinçtir $^{125}$. Mahfazalar için sarı mandal, İngiliz Menteşesi tercih edilmiştir. Bu sandıklar taşınırken dört kez Galata'ya gidilmiştir ${ }^{126}$. Satın alınma esnasında on dört hamal bu sandıkları taşımıştır ${ }^{127}$. Sandıkların büyüklüğü aslında çeyizin de büyüklüğü hakkında ipucu

115 Majolika, Endülüs Çinisi. Doğan Hasol, Mimarlık ve Yapı Sözlüğ̈̈, Yapı Yayınları, İstanbul 2003, s. 142.

116 BOA, HH.d, 2432, 15 Şubat 1320 (28 Şubat 1905), s. 35.

117 BOA, HH.d, 5947, 13 Şubat 1320 (26 Şubat 1905), s. 7.

118 Açık yeşille mavi arasındaki renk.

119 BOA, HH.d, 24342, 15 Şubat 1320 (28 Şubat 1905), s. 35.

120 Sabah, no. 237, 26 Teşrinisani 1876 (26 Kasım 1876), s. 2.

121 284. 658 kuruşluk. BOA, HH.d, 5947, 9 Haziran 1321 (22 Haziran 1905), s. 23.

122 BOA, Y.PRK.KOM, 16/13, lef 1, 5 Z 1325 (9 Ocak 1908).

123 Murassa: yaldızlamak, mücevherle işlemek.

124 Bu kutular arasında kırmızı mineli Avrupakârî tuğralı murassa' kutu, mineli zümrütlü ve elmaslı murassa' kutu, murassa' kebir Avrupakârî kutu, murassa' kutu, kebir murassa' enfiye kutusu, murassa' kutu, kebir murassa' tuğralı kutu, murassa' enfiye kutu. BOA, MB, 1036/19, lef 3.

125 BOA, MB, 1000/68, 19 Teşrinievvel 1299 (31 Ekim 1883).

126 BOA, MB, 1136/20 lef 3, 28 Şubat 1320 (13 Mart 1905).

127 BOA, MB, 1000/68, 19 Teşrinievvel 1299 (31 Ekim 1883). 
vermektedir ${ }^{128}$. Nâile Sultan'ın çeyizini Kuruçeşme'ye kadar taşıyan hamallara 810 kuruş ödeme yapılmıştır'129. Nâile Sultan'ın Yıldız Sarayı'ndan Ortaköy'e gece giden cihâziyesinin nakli için 7 kişi, esnâ-yı cemiyette kullanılan 3 adet paravanı taşımak için 6 kişi ve diğer eşyaların naklinde ise 7 kişi toplam 20 kişi vazifelendirilmiştir ${ }^{130}$.

\section{Düğün Hazırlıklarının Ekonomik Boyutu}

Saray mensuplarının XIX. yüzyılın ilk çeyreğine gelene kadar daha mazbut gizli ve gizemli saray yaşantısı içerisinde bir düzen kurarlarken, sonrasında bu anlayışın uzağında bir davranış sergiledikleri ifade edilmektedir. Sultan Abdülmecid'in iktidar yılları, saray kadınlarının israf ve serbestiyet içinde hareket ettikleri bir dönem olarak izah edilmektedir ${ }^{131}$. Öyle ki, Cevdet Paşa, Tezâkir' de sultan düğünleri sebebiyle Hazîne-i Hâssa'nın borçlarının çok yüksek olduğunu yazmıştır ${ }^{132}$. Uzunçarşı11, babaları sağ olan sultanefendilerin düğünlerinin organize edilmesini fevkalâde ifadesiyle anlatmış ve damatların çokça masraf ettiğine vurgu yapmıştır ${ }^{133}$. Uluçay, padişahın sultan düğünlerinde hazinenin ağzını açtığını Harem'de ve İstanbul'da parayı su gibi akıttığını paylaşmıştır ${ }^{134}$. Padişah kızlarının genellikle görkemli yapılan ve hazineye yük getirdiği söylenen düğünleri ${ }^{135}$ sonrasında masraf kelimesinin temel anlamına bakarak meseleye yön verip Nâile Sultan'ın çeyiz masrafı özelinde konunun ele alınması gerektiğini düşünmekteyiz. Masraf cepten çıkan akçe, satın alma ve ihtiyaca karşı verilen meblag $\breve{g}^{136}$ olarak karşımıza çıkmaktadır. İsrâf kelimesi ise mübalağalı bir ifade ile lüzumsuz yere ve fazla olarak mal vesâireyi sarf etme anlamında kullanılmaktadır ${ }^{137}$. $\mathrm{Bu}$ doğrultuda Nâile Sultan'ın düğün hazırlıklarının ekonomik boyutu hakkında neler söyleyebiliriz?

II. Abdülhamid yıllarında Mâliye Hazînesi ve Hazîne-i Hâssa borç altındadır; özellikle de düğün harcamalarının ve bu kapsamda saray masraflarının gelir-gider durumunun değerlendirilmesi için Mahmud Paşa görevlendirilmiştir. Tasarrufun bir ayağını sultan ve şehzâdeler için yapılan harcamaların indirilmesi oluştursa da Hazîne-i Hâssa'nın borçları

128 BOA, MB, 1136/20 lef 3, 13 Mart 1905 (13 Mart 1905).

129 BOA, HH.d, 5947, 19 Şubat 1320, s. 10.

130 BOA, MB, 1036/20, lef 5, 27 Şubat 1320 (12 Mart 1905); Nâile Sultan'ın levâzım-l cihâziyelerinde görevlendirilen isimler arasında Depo Memuru Hasan Efendi, Nezâret Odacısı Hacı Mustafa Ağa, Tahrirât Odacısı Ali Ağa, Heyet-i Teftişiye Odacısı İbrahim Ağa ve iki tablakârın yanı sıra tamirhâne-i hümâyûn ketebesinden Cemil Bey vazifelendirilmiştir. Hademe hizmeti karşılığında 1.320 kuruş komisyonca karşılanmıştır. BOA, MB, 1036/20 lef 6.

131 Ali Akyıldız, Mümin ve İsraf Bir Padişah Kızı Refia Sultan, Kapı Yayınları, İstanbul 2015, s. 293.

132 Cevdet Paşa, Tezâkir 13-20, yay. haz. Cavid Baysun, Türk Tarih Kurumu, Ankara 1986, s. 22-23.

133 İsmail Hakkı Uzunçarşılı, Osmanlı Devleti'nin Saray Teşkilatı, TTK Basımevi, Ankara 1998, s. 161.

134 Uluçay, Harem II, s. 97.

135 Alderson, a.g.e., s. 156.

136 Sâmi, "masraf", a.g.e., s. 1357.

137 Sâmi, "isrâf”, a.g.e., s. 108. 
dönem içerisinde sorun teşkil etmeye devam etmiştir ${ }^{138}$. Sultan II. Abdülhamid mevzûya hassasiyetle yaklaşmış, kızlarından bazılarının çeyiz masraflarını kendisi karşılamıştır. İçinde bulunulan koşullar dolayısıyla kimi zaman sultanların toplu düğünleri yapılmış kimi zaman ise düğün tarihleri ertelenmiştir ${ }^{139}$.

Nâile Sultan’ın düğün hazırlıkları XX. yy. başlarından itibaren organize edilmesine rağmen 1905 yılına gelindiğinde hâlâ merasim yapılamamıştır ${ }^{140}$. Nâile Sultan'ın çeyiz hazırlığı ve düğün icrası için devletin ve maliyenin koşulları göz önünde bulundurulmuştur. Örneklendirecek olursak bazı resmî muamelenin terk edilmesi istenirken, çeyiz için o zamana kadar alınmış olan eşya ile yetinilmesine vurgu yapılmıştır. “ ...ş̧imdi sultanefendi bendeleri için selâtin-i mâziye sûret-i muntazamada cihâz-ı behiyyesine ve düğün icrasına gerek ahvâli hâzıra ve gerek kuvve-i mâliye müsâid olmadı̆̆ından böyle bir takım resmî şeylerin şimdiye kadar cihâz olarak ihzâr olunan eşya ile iktifâ buyrulması ve tensîb-i fermân buyrulacak ...". Bilâ teklif sadece cemiyet-i velîmenin icrası istenmiştir ${ }^{141}$.

Nâile Sultan'ın velîme cemiyeti için gerekli ihtiyaçlarının tedariki, diğer sultanların masraf-ı cihâziyeleri kıyas edilerek tespit edilmiştir. Harcanması lüzum görülen miktar Hazîne-i Hâssa'ya peyderpey ödenmiştir ${ }^{142}$. Nâile Sultan'ın bir taraftan çeyiz hazırlıkları devam ederken, diğer taraftan kendisine uygun görülen sâhilhânenin tefrişatı tamamlanmıştır. Nâile Sultan'ın tahsisât-ı cihâziyelerinin onun şân-ı ulviyet-i nişanlarına uygun olmak şartıyla 10.000 Lira civarında olması bildirilmiştir. Bu miktar techizât, tefrişât ve sâhilhânenin süslenmesine sarf olunmuştur ${ }^{143}$. Gazete haberleri göz önüne alındığında, II. Abdülhamid yıllarında çeyiz alayının yapılmadığı düğün alaylarının önceki yıllara göre daha sönük geçtiği düşünülmektedir. Zarûrî sayıda görevli eşliğinde bir organizasyon söz konusudur. Bu yaklaşımda, Sultan II. Abdülhamid'in tasarruf hassasiyeti göz önünde bulundurulmalıdır. Nâile Sultan'ın sûr-ı hümâyûnu için vuku bulan çeşitli harcamalar, toplam 24.820,84 Liradır. $\mathrm{Bu}$ dönemde en yüksek harcamanın yapılmış olduğu düğün olarak ifade edilmektedir ${ }^{144}$. Diğer taraftan harcamanın 10.000 Lirasının Emlâk-1 Hümâyûn tarafından karşılanması planlanmıştır. Aradaki fark 14.820,84 Lira olarak karşımıza çıkar ki; bu rakam ise diğer

138 Terzi, a.g.e., s. 130-132.

139 Uluçay, Harem II, s. 91; Kırpık, a.g.e., s. 139-145, 150-152.

140 Sultan çeyizleri için ayrılan miktar: Behice Sultan: 100.000 Lira (1876), Seniha Sultan: 100.000 Lira (1876), Mediha Sultan: 7.500 Lira (1881), Naile Sultan: 7.500 Lira (1881), Nazime Sultan: 15.020 Lira (1889), Saliha Sultan: 15.020 Lira (1889), Esma Sultan: 15.020 Lira (1889), Naime Sultan: 16.749,29 Lira 81889), Hatice Sultan: 13.660 Lira (1901), Fehime Sultan: 13.660 Lira (1901), Münire Sultan: 18.665,5 Lira (1907), Fatma Sultan: 18.665,5 Lira (1907), Rukiye Sultan: 6.000 Lira (1909), Behiye Sultan: 6.000 Lira (1909), Adile Sultan: 6.000 Lira (1911), Nemika Sultan: 6.000 Lira (1911), Refia Sultan: 6.000 Lira (1912), Atiye Sultan: 6.000 Lira (1912). A.y.

141 BOA, Y.PRK.AZJ, 46/126, 29 Z 1320 (28 Mart 1903).

142 BOA, Y.PRK.KOM, 16/13, lef 2 Kânunusani 1323 (Ocak 1908).

143 BOA, Y.MTV, 271/28, 4 Şubat 1320 (17 Şubat 1905).

144 Behice ve Seniha Sultanların düğünleri hariç tutulduğunda. Kırpık, a.g.e., s. 144-145, 190-193. 
sultanlara harcanmış miktara yakındır ${ }^{145}$. Padişahın masrafın bu kısmını, kişisel gelirinden ödemek istediği üzerinde durulabilir ${ }^{146}$. Sultan düğünü için ayrılan miktar sadece ekonomik boyutuyla değil, sosyo-kültürel ve geleneksel anlayışla okunabileceği gibi sarayın imajının sergilemesi olarak da görülebilir. Bu miktar, padişahın kızına verdiği kıymetle birlikte Yıldız Sarayı'nın gücünü ve pozisyonunu sergilemektedir. Sultan ailesinin inşâsı bağlamında bu miktarı, devlet törenlerinden padişahın iktidar simgelerine kadar uzanan çeşitlilikte imaj algısının bir bedeli olarak değerlendirebiliriz.

\section{Nikâh}

Tarihler 27 Şubat 1905'i gösterdiğinde, Nâile Sultan'in Arif Hikmet Bey ile dest-i izdivâcı soğuk bir kış günü gerçekleşmiştir. Dönem basınında Nâile Sultan ile Arif Hikmet Bey’in nikâhı duyurulurken ${ }^{147}$ merasim öncesi nikâhın yapılacağı yer ve zaman da bildirilmiştir. İkdam Gazetesi'nde hicrî takvime göre 22 Zilhicce Pazartesi günü saat beş buçuk sıralarında ${ }^{148}$ Yıldız Sarayı'nda Nâile Sultan ile Arif Hikmet Bey'in nikâh akitlerinin gerçekleştiği ilan edilmiştir ${ }^{149}$. Nikâhta, Nâile Sultan'ın vekili Dahiliye Nâzırı Memduh Paşa olurken, şahitliğini Ticaret ve Nâfia Nâzırı Zihni Paşa ile Sadrazamdan ebu'l Hüda Efendi yapmışlardır. Arif Hikmet Bey’in vekili Adliye Nâzırı Abdurrahman Paşa iken, Tophane-i Amire Müşiri Zeki ve Evkaf-1 Hümâyun Nâzırı Turhan Paşa şahitlik etmişlerdir ${ }^{150}$. Akit sırasında Sadrazam Ferid Paşa, Şeyhülislam Mehmed Cemâleddin Efendi, vekiller, mabeyn erkânı ve bendegân hazır bulunmuştur. Yıldız Sarayı'nda gerçekleşen nikâh sonrasında Damat Arif Hikmet Bey, annesiyle birlikte Sultan II. Abdülhamid'i ziyaret ederek şükranlarını sunmuşlardır ${ }^{151}$. Vekillerin eşlerinden arzu edenler, Nâile Sultan'ın sâhilhânesine teşrif etmişlerdir ${ }^{152}$. Nâile Sultan'1 Ermeni Patriği tebrik ederken ${ }^{153}$, İngiltere kralının tebriği sefir vasıtasıyla bildirilmiştir ${ }^{154}$. Alman elçisi Baron Marescehal von Biberstein’in zevcesi de

145 BOA, Y.MTV, 279/32 9 Haziran 1321 (22 Haziran 1905).

146 Emlâk-1 hümâyûn hakkında detaylı bilgi için bkz. Arzu T. Terzi, Haine-i Hassa Nezareti, Türk Tarih Kurumu Basımevi, Ankara 2000, s. 81-116.

147 BOA, İ.HUS, 126/58, 14 Şubat 1320 (27 Şubat 1905).

148 İkdam, no. 3849, 28 Şubat 1905, s. 1.

149 Sabah, no. 5520, 27 Şubat 1905, s. 1.

150 BOA, İ.HUS, 126/58, 22 Z 1322 (27 Şubat 1905); BOA, YPRK.MŞ, nr. 8/10, lef 2.

151 İkdam, no. 3849, 28 Şubat 1905, s. 1; BOA, ML.EEM, nr. 508/91, lef 3, 14 Şubat 132 (27 Şubat 1905); Sultan II. Abdülhamid atiyyye-i seniyye olarak Damat Arif Hikmet Bey'e 100.000 kuruş ihsan buyurmuştur. BOA, HH.d, 5947, 14 Şubat 1320, s. 8; Cemiyet-i mesûdada akd-i avâid olarak: 34.500 kuruş harcanmıştır. Akd-i cemiyet için Sultan II. Abdülhamid'in birinci ve ikinci imamlarına 10.000 kuruş, teşrifatçı efendiye 5.000 kuruş, ser müneccim efendiye 4.000 kuruş, Ayasofya Camii kürsü şeyhine 3.000 kuruş ve Sultan Ahmed Camii kürsü şeyhine 2.500 kuruş ayrılmıştır. BOA, HH.d, 5947, 14 Şubat 1320, s. 8.; Sultanefendinin cemiyet- $i$ mesûdaları Cuma gecesinde yatsı namazını eda eden imam efendiye de 1.000 kuruş ödeme yapılmıştır. BOA, HH.d, 5947, 21 Şubat 1320 (6 Mart 1905), s. 11.

152 BOA, BEO, 2516/188667 lef 1, 16 Şubat 1320 (1 Mart 1905); BOA, İ.HUS, 12/60 lef 116 Şubat 1320 (1 Mart 1905).

153 Sabah, no. 5523, 17 Şubat 1320 (2 Mart 1905), s. 1.

154 BOA, HR.TH, 315/82, 21 Şubat 1320 (6 Mart 1905); BOA, BEO, 2520/188960 lef 1, 21 Şubat 1320 (6 Mart 1905). 
Nâile Sultan'a İmparatoriçe Augusto Victoria adına tebriklerini sunarken, küçük mücevherli bir saati buketle birlikte takdim etmiştir ${ }^{155}$.

Nikâh sonrasında 27 Şubat 1905 Pazartesi akşamı haremdeki ziyafet için Yıldız Sarayı'ndan 5 tabla yemek getirilmiştir ${ }^{156}$. Menüde düğün çorbası, mantarlı kuzu kızartması, sebzeli tavuk dolması, etli enginar, bakla, tavuklu çiçek Amasya bamyası, pilav, kremalı peynirli ve kıymalı börek, sardalya ve havyar yer almaktadır. Tatlı olarak baklava tatlısı, elma tatlısı, zerde ve tavuk göğsü hazırlanmıştır. Meyve olarak mandalina, armut, elma, portakal, salatanın yanında içecek olarak limonata ikram edilmiştir. Ertesi gün de bu uygulama devam etmiştir. Yıldız Sarayı'ndan bu sefer sabah ve akşam olmak üzere iki kere yemek gönderilmiş ve başta harem olmak üzere çeşitli görevlilere dağıtılmıştır. Sabah 10, akşam ise 34 tabla yemek dağıtılmıştır. Muhtemeldir ki; bu yemek sarayda bulunan çalışanlar için hazırlanmıştır. Nâile Sultan ve Damat Arif Hikmet Paşa ile birlikte haremağalarına, baltacı hademelerine, elektrik, ebniye ambarı, mefruşat memurlarına, polis, jandarma ve kethüdaya ziyafet verilmiştir. ${ }^{157}$

\section{Nâile Sultan'ın İkamet Ettiği Mekânlar}

Evlenecek padişah kızı için saray, köşk, konak, sâhilhâne ya da sahilsaray tahsis edilirken ${ }^{158}$ mevcut uygulamalarda damadın durumunun ve sultanefendinin itibarının da göz önünde bulundurulduğu âşikârdır ${ }^{159}$. Zamanla padişahların kardeşlerinin ve kızlarının evlendikten sonra Haliç, Eyüp, Boğaziçi kıyıları Ortaköy, Kuruçeşme, Akıntıburnu ve Arnavutköy güzergâhında İstanbul halkına yakın sâhilsaraylara yerleşmeleri onların hanedan içerisindeki konumları için kıymetli bir süreç olmuştur. Bir taraftan sultanefendilerin padişah sarayını temsilen yeni yaşam alanlarında imparatorluk âdabını ve usûlünü sergilemeleri, onlara atfedilen statünün göstergesi olarak ifade edilebilir. Diğer taraftan sultanefendilerin adları ile anılan bu mekânlar onları, padişah sarayından bir nebze de olsa bağımsızlaştırmıştır ${ }^{160}$.

İlk olarak eski sadrazamlardan merhûm Cevad Paşa'nın ikamet ettiği ${ }^{161}$ Nişantaşı'ndaki hanesinin, Nâile Sultan'a verilmesi için gerekli düzenlemelerin yapılması istenmiştir ${ }^{162}$. Bu süreçte, paşanın ailenin ise münasip bir konağa yerleştirilmesi uygun görülmüştür ${ }^{163}$. Konak

155 A. Osmanoğlu, Babam Sultan Abdülhamid, s. 58.

156 Dipnotta yemeğin, Yıldız Sarayı'ndan nereye getirildiği belirtilmiyor. Nâile Sultan'ın sâhilsarayına getirildiğini düşünmekteyiz.

157 BOA, HH.d, 24342, 14 Şubat 1320 (27 Şubat 1905), s. 1, 14-34.

158 Hazine-i Hassa Nezareti hakkında detaylı bilgi için bkz. Terzi, Hazine-i Hassa Nezareti.

159 Uluçay, Harem II, s. 114.

160 Tülay Artan, "Boğaziçi'nin Çehresini Değiştiren Soylu Kadınlar ve Sultanefendi Sarayları", İstanbul, sayı 3, İstanbul 1992, s. 109-118.

161 BOA, Y.PRK.DFE, 1/67, 24 Mart 1319 (6 Nisan 1903); BOA, Y.PRK.BŞK, 63/10, 2 Eylül 1316 (15 Eylül 1900); BOA, HH.İ, 153/58, lef 1, 21 Kânunusani 1318 (3 Şubat 1903).

162 BOA, YPR.DFE, 1/67 lef 1, 14 Mart 1319 (27 Mart 1903).

163 BOA, İ.HUS, 85/5, 14 Teşrinievvel 1316 (27 Ekim 1900). 
alındıktan sonra, birtakım masraflar yapılsa da ${ }^{164}$ sultanın ve eşinin bu mekânda yaşadığına dair bir malumata ulaşılamamıştır. İstanbul'da Nâile Sultan adı ile bilinen koru, Ortaköy ile Kuruçeşme arasında sahil yolunda Defterdarburnu'ndan kuzeybatıya yükselen dik eğimli yamaç ve tepeye uzanan arazidir. Yaklaşık olarak 4,9 hektar olan bu korunun Sultan II. Abdülhamid'in kızı Nâile Sultan'a ait olduğu anlatılmaktadır ${ }^{165}$. Aslında Kuruçeşme, saray için önemli semtlerden birisidir. Kuruçeşme, padişahın özel izniyle oturulabilen XIX. yüzyılın başlarında İstanbul'un muteber bölgeleri arasında bulunmaktadır ${ }^{166}$. Bardakçı, Nâile Sultan'ın Kuruçeşme'de sonraları kömür deposu, akabinde harabe olarak bilinen sahil saraylardan birisinde oturduğunu yazmaktadı1 ${ }^{167}$. Arşivde konu ile ilgili ulaşabildiğimiz evrakta, Nâile Sultan'ın Kuruçeşme'de Bozcaadalı Hasan Paşa Yalısı'nda ikâmet ettiği bilgisine ulaşılmıştır ${ }^{168}$. Merhûm Bahriye Nâzırı Hasan Paşa'nın Sâhilhânesi’nin ve arka tarafında bulunan köşkün Nâile Sultan adına satın alınması için gerekli işlemlerin yapılması istenmiştir. Bu süreçte, sâhilhânenin ve köşkün satışı için gerekli işlemlerin yapılmaması dolayısıyla muamelenin bir an önce icrası ifade edilmiştir ${ }^{169}$.

164 BOA, ML.EEM, 464/8 lef 1, 16 Kânunuevvel 1319 (29 Aralık 1903).

1651924 yılında yurtdışına çıkmak zorunda kalan isimler arasında Nâile Sultan da vardır. 1952 yılında tekrar yurda dönmüştür. Bu zaman içerisinde mülkünü İstanbul'un kumaş tüccarlarından Namık Özsoy'a satmıştır. 1980'li yıllarda koruda iki katlı köşk ve villalar yapılmıştır. Nâile Sultan’a ait köşk restore edilmiştir. Faik Yaltırık, "Korular", Dünden Bugüne Beşiktaş, ed. Nuri Akbayar, Beşiktaş Belediye Başkanlığı, Beltur, İstanbul 1998, s. $10-12$.

166 19. yy. başlarında Ortaköy Defterdarburnu'ndan Kuruçeşme’ye uzanan alanda ilk yalı, III. Mustafa'nın kızı Hatice Sultan'ın Neşetâbâd Sahil Sarayı idi. Sultanın vefatı ile yalı yıktırılıp II. Abdülhamid'in kızları Zekiye ve Nâime sultanlar için iki eş saray inşa ettirilmişti. Defterdâr İbrahim Paşa Camii'nden sonra ise Sadrazam Yusuf Paşa'nın kardeşi Süleyman Bey Yalısı gelmekte idi. Hatice Sultan bu yalıyı maiyeti için kullanmıştı. El değiştiren bu yalının sonrasında II. Abdülhamid tarafından satın alınarak kızı Nâile Sultan'a hediye edildiği söylenmektedir. Tülay Taş̧̧ığlu-Zeynep Tülün Özgen, "Kuruçeşme", Dünden Bugüne Beşiktaş, ed. Nuri Akbayar, Beşiktaş Belediye Başkanlığı, Beltur, İstanbul 1998, s. 44-45.

167 Murat Bardakçı, Neslişah Cumhuriyet Döneminde Bir Osmanlı Prensesi, Everest Yayınları, İstanbul 2011, s. 112 .

168 Murat Belge, Boğaziçi’nde Yayllaar İnsanlar, İletişim Yayınları, İstanbul 1992, s. 32; Şehsuvaroğlu da, Defterdar Burnu'nda Kaptan-1 Derya Hasan Paşa Yalısı'nın Nâile Sultan'a verildiğini söylemektedir. Askeri Temyiz Reisi Fazıl Efendi'nin küçük bir yalısı da Naciye Sultan'ın ikametgahıdır. Ardında Sultan Abdülaziz'in kızlarından Nâzıma Sultan'a ait yalı mevcuttur. Halûk Y. Şehsuvaroğlu, Boğaziçi'ne Dair, Türkiye Turing ve Otomobil Kurumu, İstanbul 2006, s. 214-215.

169 BOA, Y.MTV, 287/96, lef 122 Mayıs 1322 (4 Haziran 1905). 


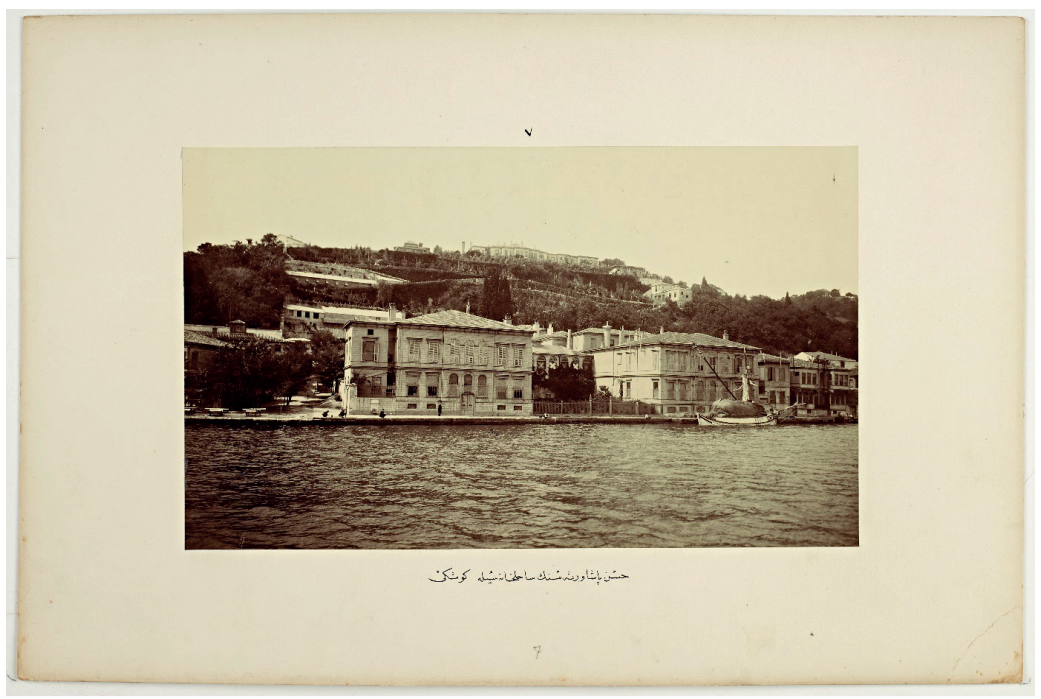

Resim 2

Hasan Paşa Veresesinin Sâhilhânesi ve Köşkü ${ }^{170}$

Nâile Sultan'ın ikametine mahsus olmak üzere Kuruçeşme'deki sâhilhânenin bedelinin Maliye tarafından, Hazine-i Hâssa tahsîsatından ayrılması bildirilmiştir. Daha önce Zekiye ve Nâime sultanlara verilen ikametler ayarında bir düzenleme yapılmıştır ${ }^{171}$. Bahriye Nâzırı sâbık Hasan Paşa merhûmun veresesine ait olup, Nâile Sultan adına satın alınan Kuruçeşme'deki sâhilhâne ve arkasındaki köşk için 11.000 Osmanlı Lirası ödenmiştir ${ }^{172}$. Nâile Sultan Köşkü'nün ehven bir şekilde döşenmesi için acele davranılması istenmiştir. Kırk oda, salon ve koridordan oluşan köşk için tasarrufa riayet edecek şekilde harcama yapılması vurgulanmıştır ${ }^{173}$.

170 İ.Ü. Nadir Eserler Kütüphanesi, II. Abdülhamid Han Fotoğraf Albümleri, no. 779-75-0007.

171 BOA, Y.MTV, 287/69, lef 1, 18 Mayıs 1322 (31 Mayis 1906).

172 BOA, HSD, CB 3/43, 6 Şubat 1320 (19 Şubat 1905).

173 BOA, HH.İ, 178/46, lef 1, 13 Mart 1321 (26 Mart 1903). 


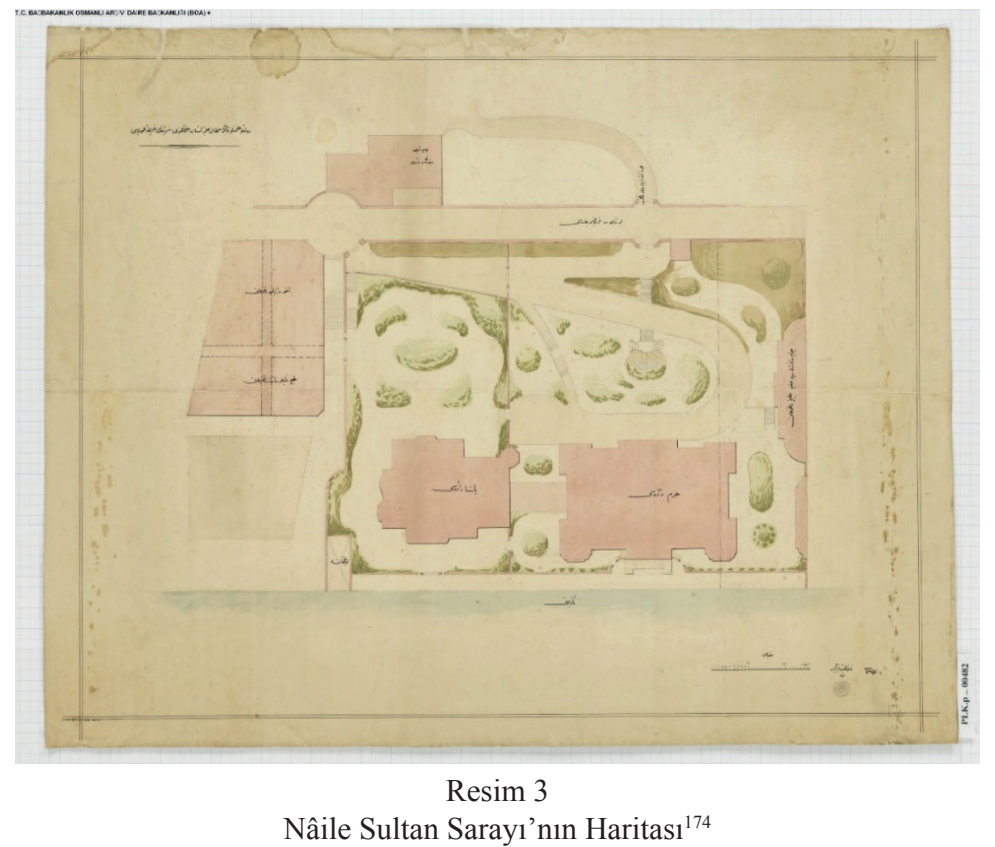

1850 ile 1860 yılları arasında inşa edilmiş olan Hasan Paşa Yalısı, sonrasında yenilenmiş ve XX. yy. başlarında Nâile Sultan'a verilmiştir. Sedat Hakkı Eldem çalışmasında Hasan Paşa Yalısı'nın, kârgir zemin kat üzerine iki ahşap kat ve çatı katından oluştuğunu yazmaktadı1 ${ }^{175}$. Nâile Sultan'ın ikametgâhı için hem sahil hem de dağ cihetinde iki mekândan söz edebiliriz: Sâhilhâne ve köşk. Siradan bir ikametgâh olan sâhilhânenin tamir edilse bile mükemmel bir daire olmaya elverişli olmadığına vurgu yapılmıştır. Dolayısıyla rıhtım üzerindeki sâhilhânenin ve dağ tarafındaki köşkün tamire ihtiyacı vardı. Sâhilhâne, Kuruçeşme'den Arnavutköy’e giden yol üzerinde idi. Sahilde olan kısmın cephesi 28 metre ve caddeden denize olan uzaklık 28 metre olup 784 metre murabbai ${ }^{176}$ teşkil etmekte idi. Dağ tarafinda olan k1smın caddeye bakan tarafi 25,60 metre uzunluğunda haritada gösterildiği cihetle 87,60 metre murabba1 derinliğinde olup set mevcuttu. 3.403,30 metre murabba1 sâhilhâne bir zemin katıyla birlikte iki kattan ibaret olup bir kısmı sahildeki arsa üzerinde idi177.

174 BOA, PLKp, 482/1.

175 Özlem Atalan, “Ortaköy-Kuruçeşme Arasındaki Sahilsaraylar; 19. Yüzyıl”, Turkish Studies, X/1 (2015), s. 83120.

1764 Nisan 1931 tarihli Resmi Gazete'de ölçüler kanunu yer almaktadır. Metre murabbaı bütün satıh ölçülerinde kullanılır. Metre murabbaı hakiki bir ölçü olmayıp itibarî bir ölçüdür. Satıhların esas ölçüsüdür. Metre murabba1-santiar: esas ölçü.

177 BOA, Y.HUS, 514/14 lef 2, 30 Temmuz 1323 (12 Ağustos 1907). 
Yalının Ortaköy tarafında bulunan selamlık binası ile harem binası arasında rıhtıma demir korkuluklarla bir bahçe açılmakta idi ${ }^{178}$. Haremin üst katında dokuz oda; alt katında ise taşlık bölümünde beş oda mevcuttu. Bahçeye bakan diğer dairenin üst katında salon; bu dairenin orta kat planında dört oda ile bir hamam, alt katında ise dört oda yer almakta idi ${ }^{179}$. Harem binası yüksek duvarlarla rıhtımdan ayrılmıştır. Yuvarlak biçimli binada deniz hamamı olduğu da düşünülmektedir. Yapının cephelerinde dikdörtgen biçimli; deniz cephesinin merkez kısımlarında ise yuvarlak kemerli pencereler tasarlanmıştır ${ }^{180}$. Arkadaki bahçede bulunan diğer bölüme geçiş köprü ile sağlanmıştır. Binaların altındaki mahzenler ve bahçenin köşesindeki ahır da bu plan içerisine dahil edilmektedir ${ }^{181}$.

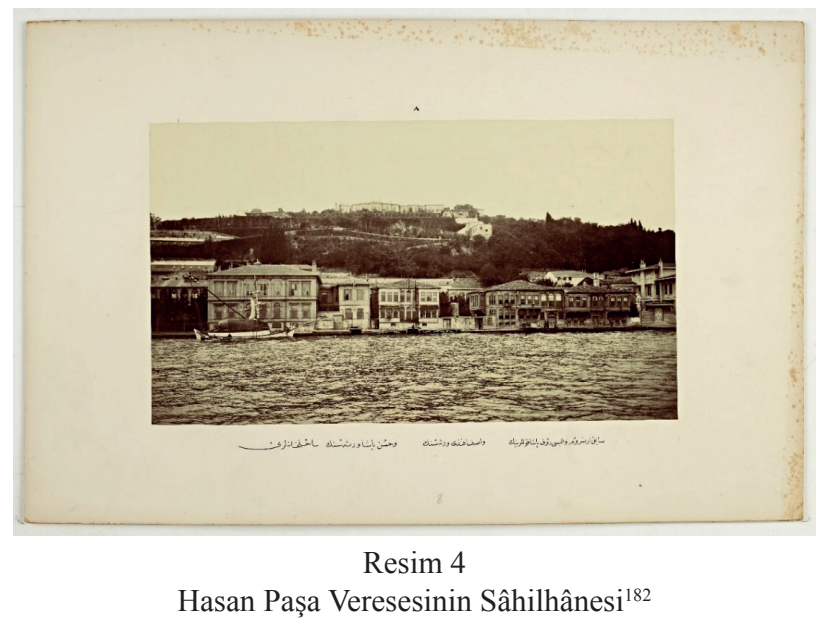

Nâile Sultan Kuruçeşme'de, 1905-1924 yılları arasında yaşamıştır ${ }^{183}$. Bu tarihler Nâile Sultan'ın evlendiği yıl kendisine tahsis edilmiş sâhilsarayında hanedanın yurt dışına çıkarılışına kadar ikamet ettiğini anlatmaktadır. Nâile Sultan ve eşi on dokuz yıl burayı kullanmışlardır ${ }^{184}$. Nâile Sultan ve eşine lala, vekil harç, makinist, kapıcı, hademe, aşçıbaşı, aşçı kalfası, aşçı çırağı, arabacı, seyis, bahçıvan başı, bahçıvan, külhancı, harem bekçisi, yalı bekçisi, tablakar hizmet etmiştir ${ }^{185}$. Sâhilsarayın iç döşemesine, düzenine ve süslenmesine özen gösterilmiştir. Sultanın köşkünün süslemeleri için çabuk davranılmasının yanı sıra daha ucuz ve hesaplı bir şekilde döşenmesi için çalışılmıştır ${ }^{186}$. Öncelikle sâhilsarayın tamirat-

178 Büyük Mecidiye Camii ve Ortaköy, ed. Mehmet Baha Tanman, Kuveyt Türk, İstanbul 2014, s. 183.

179 BOA, HH.d, 1159, s. 13.

180 Büyük Mecidiye Camii ve Ortaköy, s. 183.

181 BOA, Y.HUS, 514/14 lef 2, 30 Temmuz 1323 (12 Ağustos 1907).

182 İ.Ü. Nadir Eserler Kütüphanesi, II. Abdülhamid Han Fotoğraf Albümleri, no. 779-75-0008.

183 Öztuna, II. Abdülhamid: Zamanı ve Şahsiyeti, s. 224.

184 BOA, HH.İ, 177/66 lef 1, 7 Mart 1321 (20 Mart 1905).

$185 \mathrm{O}$ dönem için vekilharç, hademe, tablakâr, inekçi yamağı kadrosu boştur. BOA, MB, 1073/45, lef 3, 24 Muharrem 1333 (12 Aralik 1914).

186 BOA, HH.İ, 177/66 lef 1, 7 Mart 1321 (20 Mart 1905). 
telvînat $^{187}$ işleri elden geçirilirken ${ }^{188}$ boyası da yapılmıştır ${ }^{189}$. Nâile Sultan'ın levâzım-ı cihâziyyeleri için hazırlanmış olan eşyaların masrafı, önceki sultanlar için tahsis edilmiş bedele uygun ayarlanmıştır ${ }^{190}$. Hereke Fabrikası'ndan halı, yaldızlı kanape, koltuk, sandalye, yaldızlı ayna, konsol, taşı orta sehpası, perde kolu, yaldızlı korniş, pirinç çengel ve dantel satın alınmıştır ${ }^{191}$. Döşeme için Hereke Fabrikası'ndan kumaşlar sipariş edilmiştir ${ }^{192}$. Mekân için sobalardan istifade edilmiştir ${ }^{193}$. Sâhilhâne elvan renkli-fanuslu kısa lamba, billur fanus, Majolik kırmızı, tirşe, billûri pembe lamba takımları ve yaldızlı fanus gümüş şamdanlarla aydınlatılmıştır. Sultan Majolik çiçek takımı-çiçeklikler ${ }^{194}$, gelin odasındaki vazolar ${ }^{195}$ ve jardinyer ${ }^{196}$ için çiçekler sipariş verilmiştir ${ }^{197}$. Havagazı ile aydınlatılan sâhilhânenin bahçe düzenlemesine de özen gösterilmiştir ${ }^{198}$. Sultanın ikametine mahsus sarayın fotoğraflarının çekilmesi için Bahriye Nâzırı Fotoğrafçıbaşısı Sami Bey vazifelendirilmiştir ${ }^{199}$. Nâile Sultan'ın ismi ile anılan sâhilhânesinde kendi saray teşkilatı doğrultusunda düzen kurması, ona aile içindeki konumunu güçlendiren bir ortam hazırlamıştır.

\section{Sonuç}

Bir sultan ailesi inşâsı söz konusu olduğunda birden fazla parametre devreye girerken, damadın ve babasının kim olacağı meselesi öncelik kazanmaktadır. Nâile Sultan ve Arif Hikmet Paşa'nın izdivacında damadın almış olduğu baba terbiyesi üzerinde durulmuş ve damadın babası da sorgulanmıştır. Nâile Sultan'ın rızası çerçevesinde şekillenen bu izdivacın, her ikisine de saadet ve mutluluk getirmesi vurgusu yapılmıştır ${ }^{200}$. Nâile Sultan'ın eşi ile birlikte çok mesut bir hayat sürmesi ${ }^{201}$, bizi evlilik inşâsında Nâile Sultan için seçilen Arif Hikmet Paşa'nın doğru isim olduğu bilgisine götürmektedir. Nâile Sultan'ın evliliğinin babasının iktidarında gerçekleşmesi, düğünün görkemli düzenlenmesini etkileyen bir faktördür. Dügüunün maddi yönü Nâile Sultan'ın tüketim tarzını ve yaşam standardını yansıtmakla birlikte yapılan harcama, Nâile Sultan'ın damat karşısındaki pozisyonuna işaret etmektedir.

\footnotetext{
187 Renk verme.

188 BOA, HH.d, 5947, 27 Şubat 1320 (12 Mart 1905), s. 13.

189 Kirpık, a.g.e., s. 156.

190 BOA, MB, 1036/25 lef 1, 16 Nisan 1321 (29 Nisan 1905).

191 BOA, MB, 1036/25 lef 2, 24 Şubat 1320 (9 Mart 1905).

192 BOA, HH.d, 5947, 16 Nisan 1321 (29 Nisan 1905), s. 21

193 BOA, MB, 1036/17, lef 5, 22 Şubat 1320 (7 Mart 1905).

194 BOA, MB, 1036/17, lef 119 Şubat 1320 (4 Mart 1905).

195 BOA, HH.d, 1159, Mart 1905, s. 13.

196 Jardinyer, söz ya da nişan gibi önemli günlerde sunum masasında kullanılan aynalı objedir.

197 BOA, HH.d, 26687, 1320 (1905), s. 26.

198 BOA, HH.İ, 177/13 lef 1, 6 Şubat 1320 (19 Şubat 1905). BOA, Y.MTV, 308/193, lef 2, 15 Nisan 1324 (23 Nisan 1908); BOA, ML.EEM, 589/37, 31 Kânunusani 1322 (13 Şubat 1907).

199 BOA, HH.d, 5947, 26 Şubat 1320 (11 Mart 1905), s. 12.

200 BOA, Y.PRK.MŞ, 8/10, lef 6, 5 Şubat 1320 (18 Şubat 1905).

201 Uluçay, Padişahların Kadınları ve Kızları, s. 180.
} 
II. Abdülhamid'in iktidar yıllarında saray harcamalarını organize eden Hazîne-i Hâssa, ahvâl-i hazıra ve kuvve-i mâliyenin durumu müsait olmadığından olumsuz etkilenmiştir ${ }^{202}$. Bu sebeple, dügün hazırlıklarında masrafların kısıtlanması ve devlet hazinesinin yükünün azaltılması düşüncesiyle de birtakım düzenlemelere gidilmiştir. Geline, damada ve yakınlarına hediye verilmesi sebebiyle ortaya çıkan yükümlülüklerin ve harcamaların terk olunması istenirken ${ }^{203}$ bu düğün özelinde, atiye verme usûlü devam etmiştir. Bununla birlikte, sultan saraylarında düzenlenen ziyafetlere lüzum olmadığının altı çizilmiştir. Daha az harcama yapılması fikri doğrultusunda, birden çok sultanın düğününün birleştirilmesine devam edilmiştir. Bazı resmî prosedürün terk edilerek, Nâile Sultan'a çeyiz için daha önceden alınmış eşya ile yetinilmesi üzerinde de durulmuştur ${ }^{204}$. Dahası tahsis edilen ikametgâh için tasarrufa uygun hareket edilmesi bildirilmiştir ${ }^{205}$. Bu cihetten yaklaşıldığgnda, II. Abdülhamid dönemindeki düğün masraflarında bir hassasiyetin oluşturulmaya çalışıldığgnı ifade edebiliriz.

Sultan kızlarının ve kız kardeşlerinin dügün törenleri, padişahlık makamının, gücünün ve ihsanlarının yansıtıldığı merasimlerdir. Bu yönüyle Nâile Sultan'ın düğünü, sarayın temsilidir. Çünkü Nâile Sultan'ın düğünü ve kendi sarayına yerleşmesi aslında, gözden uzak Sultan II. Abdülhamid'in Yıldız Sarayı'ndaki yaşantısının bir devamıdır. Nâile Sultan'ın giyiminden kuşamına, takısından, sâhilsarayına, hizmetlilerine, tefrîşatına, çeyiz için harcananlara, bir bütün olarak bakıldığında Yıldız Sarayı sergilenmektedir. Padişahın vakar ve haysiyet sahibi kız1 ${ }^{206}$ Nâile Sultan, babası II. Abdülhamid'in en sevdiği çocuklarından birisi idi ${ }^{207}$. Yine onun adı, menkul-gayrimenkul birikimiyle de padişahın çocukları arasında hayatları boyunca sıkıntı çekmeden yaşayan isimler arasında zikredilmekteydi. Bu sebeple Nâile Sultan'ın düğün hazırlıklarındaki ihtişâmı, düğün sonrasındaki yaşantısından, sürgün yıllarına $^{208}$, hatta ömrünün sonuna kadar devam ettirdiği anlaşılmaktadır ${ }^{209}$.

Hakem Değerlendirmesi: Dış bağımsız.

Çıkar Çatışması: Yazar çıkar çatışması bildirmemiştir.

Finansal Destek: Yazar bu çalışma için finansal destek almadığını beyan etmiştir.

Peer-review: Externally peer-reviewed.

Conflict of Interest: The author has no conflict of interest to declare.

Grant Support: The author declared that this study has received no financial support.

202 Terzi, Hazîne-i Hâssa Nezâreti, s. 130-132.

203 Sabah, no. 237, 26 Teşrinisani 1876 (26 Kasım 1876), s. 2.

204 BOA, Y.PRK.AZJ, 46/126, 15 Mart 1319 (28 Mart 1903).

205 BOA, HH.İ, 178/46 lef 1, 13 Mart 1321 (26 Mart 1903).

206 Uluçay, Padişahların Kadınları ve Kızları, s. 180; Bardakçı, Neslişah, s. 112.

207 Bardakçı, Son Osmanlılar, s. 184.

208 Sürgün yıllarında da yetiştirilme tarzı, alışkanlıklar, saray teşrifatı ve gelenekleri çerçevesinde yaşamışlardı. Arif Hikmet Paşa 23 Nisan 1942'de Beyrut'ta, Nâile Sultan ise 25 Kasım 1957 y1lında Suadiye'de vefat etmiştir. Bardakçı, Neslişah, s. 112.

209 Bardakçı, Son Osmanlılar, s. 184. 


\section{Kaynakça/References}

\section{Arşiv Kaynakları}

Başkanlık Osmanlı Arşivi (BOA)

Bâb-1 Ali Evrak Odası (BEO)

Dahiliye Nezareti Mektûbî Kalemi (DH.MKT)

Hânedan Defteri (A.DVNSHN.d)

Hazîne-i Hâssa Tasnifi

Defterler (HH.d)

İrâde (HH.ì)

Hâriciye Nezâreti

İstişâre Odası (HR.HMŞ.IŞO)

Nezâreti Tahrîrat (HR.TH)

İrâde Tasnifi

Dosya Usûlü (İ.DUİT)

Taltîfat (İ.TAL)

Mâbeyn-i Hümâyûn

Evrak (MB)

İrâde (MB.İ)

Mâliye Nezâreti Emlak-i Emîriyye Müdüriyeti (ML.EEM)

Plan- Proje- Kroki (PLK)

Satın Alınan Evrak Cavit Beysun Evrakı (HSD.CB)

Şûrâ-yı Devlet (ŞD)

Yıldız Tasnifi

Esas Evrak1 (Y.EE)

Husûsî Mârûzat (Y.HUS)

Mütenevvi Mârûzat (Y.MTV)

Arzuhal Jurnal (Y.PRK.AZJ)

Başkitabet Dairesi Maruzat (Y.PRK.BŞK)

Defter-i Hakani Nezâreti Mârûzatı (Y.PRK.DFE)

Elçilik, Şehbenderlik ve Ateşemiliterlik (Y.PRK.EŞA)

Komisyonlar Mârûzatı (Y.PRK.KOM)

Maliye Nezareti Mârûzat (Y.PRK.ML)

Mütenevvi Mârûzat (Y.MTV)

Meşîhat Dairesi Mârûzatı (Y.PRK.MŞ)

Nâme-i Hümâyûnlar (Y.PRK.NMH)

Mabeyn Erkanı ve Saray Görevlileri Mârûzatı (Y.PRK.SGE)

Umûmî (Y.PRK.UM) 


\section{Kitaplar ve Makaleler}

Abdülaziz Bey, Osmanlı Adet Merasim ve Tabirleri, I, Türk Tarih Vakfı Yurt Yayınları, İstanbul 1995.

Açba, Leyla, Bir Çerkes Prensesinin Harem Hatıraları, yay. haz. Edadil Açba, Timaş Yayınları, İstanbul 2010.

Aktan, Hamza, "Sihriyet", DİA, c. XXXVII, s. 111-112.

Akyıldız, Ali, Mümin ve İsraf Bir Padişah Kızı Refia Sultan, Kapı Yayınları, İstanbul 2015.

Alderson, Anthony Dolphin, Osmanlı Hanedanın Yapısı, yay. haz. Mustafa Armağan, çev. Şefaettin Severcan, İz Yayıncılık, İstanbul 1998.

Artan, Tülay, "Osmanlı Elitinin Yemek Tüketiminin Bazı Yönleri: Değişken Bir Yüzyılda Temel Gıdalar, Lüks Tatlar ve Tadımlıkların İzinde", Tüketim Araştırmaları ve Osmanlı İmparatorluğu Tarihi 15501922, ed. Donald Quataert, çev. Tanju Günseren, Alfa Araştırmaları, İstanbul 2020, s. 144-145. s. $109-118$.

, "Boğaziçi’nin Çehresini Değiştiren Soylu Kadınlar ve Sultanefendi Sarayları”, Istanbul, 3 (1992),

Bağçe, Betül Kübra, II Abdülhamid'in Kızı Nâime Sultan'ın Hayatı, Marmara Üniversitesi Sosyal Bilimler Enstütüsü İlahiyat Anabilim Dalı, İslam Tarihi Bilim Dalı, Yayınlanmamış Yüksek Lisans Tezi, İstanbul 2008.

Bardakçı, Murat, Son Osmanlılar Osmanlı Hanedanının Sürgün ve Miras Öyküsü, İnk1lap, İstanbul 2007. , Neslişah: Cumhuriyet Devrinde Bir Osmanlı Prensesi, Everest Yayınları, İstanbul 2011.

Bilgin, Bülent, "Yıldız Saray1", DİA, c. XLIII, 541-544.

Büyük Mecidiye Camii ve Ortaköy, ed. Mehmet Baha Tanman, Kuveyt Türk, İstanbul 2014.

Cevdet Paşa: Tezâkir 13-20, yay. haz. Cavid Baysun, Türk Tarih Kurumu, Ankara 1986.

Demirel, Fatmagül, Dolmabahçe ve Yıldız Saraylarında Son Ziyaretler, Son Ziyafetler, ed. Lütfü Tınç, Doğan Kitap, İstanbul 2007.

Ertuğrul, Sara: Geçmiş Zaman Olur ki..., anlatan Mevhibe Celâlettin, M. Sıralar Matbaası, İstanbul 1953. Georgeon, François, Sultan Abdülhamid, çev. Ali Berktay, İletişim, İstanbul 2015.

Gündoğdu, Artemur Orkun, Osmanlı/Türk Müzik Kültüründe Avrupa Müziğinin Yaygınlaşması Süreci ve Levanten Müzikçiler, Başkent Üniversitesi Sosyal Bilimler Enstitüsü, Yüksek Lisans Tezi, Ankara 2016.

Haremden Sürgüne Bir Osmanlı Prensesi II. Abdülhamid'in Gelini Mislimelek Hanım, İstibdat Döneminin Bilinmeyenlerini Anlatıyor, haz. Nemika Deryal Marşanlığlu, İnkılap, İstanbul 2011.

Hasol, Doğan, Mimarlık ve Yapı Sözlüğü, Yapı Yayınları, İstanbul 2003.

Hülagü, M. Metin “Gazi Osman Paşa”, DİA, c. XIII, s. 464-465.

Karaca, Filiz, “Kürk”, DİA, XXVI, 568-570.

Karateke, Hakan T., Padişahım Çok Yaşa, Kitap Yayınevi, İstanbul 2004.

Kırpık, Cevdet, Haremin Son Yüzyılı Sultanlar ve Damatlar, Timaş, İstanbul 2012.

Osmanoğlu, Ayşe, Babam Sultan Abdülhamid, Timaş, İstanbul 2019.

Osmanoğlu, Şadiye, Babam Abdülhamid Saray ve Sürgün Yılları, Timaş, İstanbul 2009.

Örik, Nahid Sırrı, Abdülhamid'in Haremi, Arba Yayınları, İstanbul 1989. , Bilinmeyen Yaşamlarıyla Saraylılar, yay. haz. Alpay Kabacalı, Türkiye İş Bankası, İstanbul 2002. 
Öztuna, Yılmaz, II. Abdülhamîd: Zamânı ve Şahsiyeti, Kubbealtı, İstanbul 2008.

Peirce, P. Leslie, Harem-i Hümayun, Osmanlı İmparatorluğu'nda Hükümranlık ve Kadınlar, çev. Ayşe Berktay, Tarih Vakfı Yurt Yayınları, İstanbul 1996.

Şehsuvaroğlu, Halûk Y., Boğaziçi’ne Dair, Türkiye Turing ve Otomobil Kurumu, İstanbul 2006.

Terzi, Arzu, Hazine-i Hassa Nezareti, Türk Tarih Kurumu, Ankara 2000. , Bezmiâlem Valide Sultan, Timaș, İstanbul 2019.

Tuncer, İbrahim, Sultan II. Abdülhamid'in Klzı Ayşe Sultan'ın Hayatı, Erciyes Üniversitesi Sosyal Bilimler Enstitüsü Tarih Anabilim Dalı Yakınçağ Tarihi Bilim Dalı Yayınlanmamış Yüksek Lisans Tezi, Kayseri 2015.

Uluçay, M. Çağatay, Padişahların Kadınları Kızları, Türk Tarih Kurumu, Ankara 1980. , Harem II, Türk Tarih Kurumu, Ankara 1992.

Uru, Cevriye, Sultan II. Abdülhamid'in Kizı Zekiye Sultan'in Hayatı (1872-1950), Marmara Üniversitesi Türkiyat Araştırmaları Enstitüsü Türk Tarihi Anabilim Dalı Yakınçağ Tarihi Bilim Dalı Yayınlanmamış Yüksek Lisans Tezi, İstanbul 2020.

Uşaklıgil, Halit Ziya, Saray ve Ötesi Anılar, yay. haz. Nur Özmel Akın, Özgür Yayınları, İstanbul 2003.

Uzunçarşı11, İ. Hakkı, Osmanlı Devleti'nin Saray Teşkilatı, 3. Baskı, TTK Basımevi, Ankara 1998.

Yılmaz, Ömer Faruk, Sultan II. Abdülhamid'in Hayatı, Çamlıca, İstanbul 2013.

\section{Süreli Yayınlar}

İkdam, no. 3849, 28 Şubat 1905.

Kadın, no. 6, 17 Teşrinisani 1324 (30 Kasım 1908); no. 8, 1 Kanunusani 1324 (14 Aralık 1908).

Sabah, no. 5520, 27 Şubat 1905; no. 5523, 2 Mart 1905.

\section{Sözlük}

Şemseddin Sâmi, Kâmûs-ı Türkî, Enderun Kitapevi İstanbul, 1989. 


\section{EKLER}

\section{Ek 1}

Nâile Sultan'ın Levâzım-ı Cihâziyeleri İçin Sarf Olunan Meblağ ${ }^{210}$

\begin{tabular}{|l|l|}
\hline Harcama Kalemleri & Kuruş \\
\hline Mücevherât & 740.000 \\
\hline Atiyye & 301.000 \\
\hline Avâid'11 $^{21}$ & 34.500 \\
\hline Takdîm & 65.000 \\
\hline Avânîn ${ }^{21}$ & 147.722 \\
\hline Nişan takımı & 37.022 \\
\hline Hediyeler & 284.658 \\
\hline Melbûsât & 136.209 \\
\hline Tefrişât & 390.382 \\
\hline Levâzım-1 beytiye & 80.947 \\
\hline Tamir & 70.342 \\
\hline Yatak takımları & 50.077 \\
\hline Kiler mutfak takımları & 33.935 \\
\hline Saraya alınan sobalar & 28.440 \\
\hline Seccâde-abdest takımları & 7.573 \\
\hline Damat beyin eşyaları & 10.436 \\
\hline Perakende & 15.071 \\
\hline Ziyâfet & 48.766 \\
\hline Toplam & $\mathbf{2 . 4 8 2 . 0 8 0}$ \\
\hline
\end{tabular}

210 BOA, Y.PRK.KOM, 16/13, lef 127 Kânunuevvel 1323 (9 Ocak 1908).

211 Gelirler.

212 Yemek, çay, kahve takımları, kâse, testi, ibrik vb. eşya. 


\section{Ek 2}

Nâile Sultan'ın Dairesinde Görevli İsimler ${ }^{213}$

\begin{tabular}{|c|c|}
\hline Vazife & İsim \\
\hline Lala Baş Ağa & Süleyman Efendi \\
\hline Lala & Hayreddin Ağa \\
\hline Lala & Emin Ağa \\
\hline Vekilharç & Boş \\
\hline Makinist & Yusuf Ağa \\
\hline Kapıc1 & Ali Ağa \\
\hline Hademe & Boş \\
\hline Aşçııbaş1 & Salih Ağa \\
\hline Arabacı başı & Mustafa Ağa \\
\hline Seyis & Abdullah A ğa \\
\hline Bahçıvanbaşı & Ali Ağa \\
\hline Bahçıvan & Bayram Ağa \\
\hline Bahçıvan & Mustafa Ağa \\
\hline Külhancı & Osman A ğa \\
\hline Külhancı & Selim Ağa \\
\hline Harem Bekçisi & Hüseyin Ağa \\
\hline Yalı Bekçisi & İsmail Ağa \\
\hline Tablakar & Şükrü Ağa \\
\hline İnekçi & Talib Ağa \\
\hline İnekçi Yamağ1 & Boş \\
\hline Paşa'nın Ağası & Ahmed \\
\hline Paşa'nın Ağası & Adem \\
\hline Aş̧̧ı Kalfası & Salih A ğa \\
\hline Aşçı Çırağ 1 & Kadri Ağa \\
\hline Aşçı Çırağ1 & Kamil Ağa \\
\hline
\end{tabular}


